\title{
TRAFFIC SPEED REPORT NO. 77
}

\section{SEPT. 1963}

$$
\text { No. } 27
$$




\section{Progress Report}

TRAFIC STIBD RERORT NO. T7

TO: $\quad$ K. B. Woods, Director

Joint Highvay Research Project Septembor 27, 1963

Frat: H. L. Nichael, Associate Director Jofnt Illghivay Research Project

711e: 8-3-3

Project: $C-36-10 \mathrm{C}$

Attached w11 be found "Trarfic Speed Report Ilo. $T$ " conducted in June of 1963. This report is the lateat phase of the Indiana continuing speed study.

It 1s cocposed of dats taloen from observations on freefloving rural arterlal highvays throughout the state, and 1t analyses the trends in trarfic speeds by highvay clnosification and vehicle type. The data shnll also be mde avallable to the Buruau of Publfe Roads for Inclusion vith other states in their annunl speod trend study.

The study and report vere conducted by Mr. Levrence Bchulman, Gradunte Assistant on our staff, under the direction of Professor H. L. Hichael.

The report is presented for information and the record, and it is requested that approval be granted to distribute coples to the Bureau of Public Roads, the Indiana State Police, the Orfice of Trafflc Safety and the Mrafre Safety Foundation.

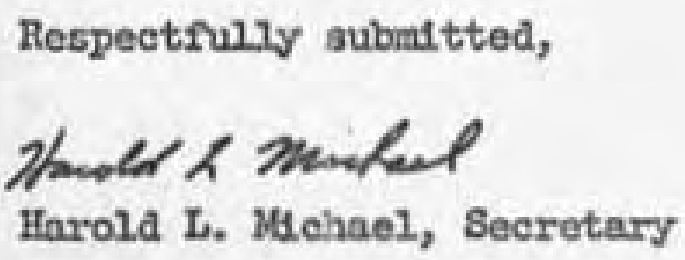

HIM: bc

Attachment

Coples:

I. I. Ashbeucher

J. R. Cocper

v. L. Doleh

V. H. Gootz

$\boldsymbol{P}$. $\boldsymbol{P}$. Havey

F. S. Han1

o. A. Leconards
J. F. MeIaughlin

R. D. Mles

R. E. xt12s

K. B. Scott

J. V. Berthe

z. J. Yoder 
Digitized by the Internet Archive in 2011 with funding from

LYRASIS members and Sloan Foundation; Indiana Department of Transportation

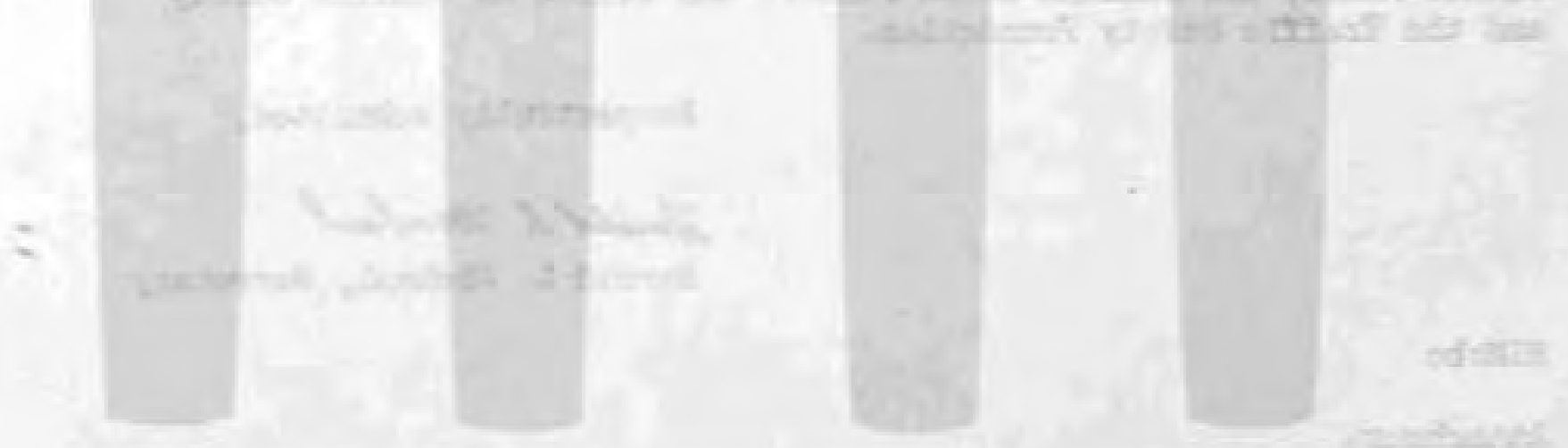




\section{Progress Report}

TRANIC SPRED RAFOE $10 . T 7$

$$
\text { by }
$$

Iexrence Schniean

Greduate Assistant

Jolnt Hlghway Research Project

File No: 8-3-3

Project No: C-36-10C

Purdue University

Lefayette, Indsana

Septeaber 27, 1963 


\section{TRAFPIC SFEED REPORT NO. $\pi 7$}

\section{Introduction}

This report is an ansiysis of spot-speed observations made during June of 1963. A11 observations vere aade on free-poving vehieles operating on level, tangent sections of rural higliways during daylight hours and under fevorable veather conditions. The data vere collected on three types of highways: two-lane, fourIane and faterstate and vere classified by direction, state and type of vehicle.

In order to analyze a representative sample of traffic speeds throughout the state the stations were located as follows:

Interstate Highays

1. I-80 0.7 wiles east of junction of SR 912

2. I-65 1.0 mile north of junction of SR $33^{4}$

3. I-74 1.0 mile east of junction of Post load

4. I-65 2.9 miles north of junction of SR 160

Four Lane Highways

5. US $31 \quad 1.2$ miles south of Junction of SR 38

6. US 521.0 mile south of south junction of $\mathrm{sR} 28$

7. US 411.0 mile north of south Junction of SR 2

8. US 521.0 nile north of Xlondyke

Two Lane Eighuays

9. US $41 \quad 1.0$ afla north of Bomel1

10. US 522.0 alles north of Teapleton

11. OS 313.0 miles south of Rochester

12. SR $25 \quad 0.7$ =1les west of Anericus 


\section{Equipment and Field Procedure}

The data for this study were obtained by use of an Blectromatic Radar Speed Meter - model No. S-5. The meter vas placed approximately three feet from the edge of the pavenent at an angle of less than $10^{\circ}$ with the centerline of the higlway. Speed inaccuracies are negligible at sall angles and corcectons vere unnecessary. At the beginning of the study a test was performed to determine the accuracy of the Radar Keter by use of the calibrated fifth wheel. Tests vere nade for speeds between 20-70 mph in increments of $10 \mathrm{mph}$, and it was found thet when an error did exist, it was at most 1/2 aph. Since the Radar Neter is calibrated in even miles per hour requiring an estination of the odd nile par hour readings, 1t was decned unnecessary to use a callbration curve for an error of $1 / 2 \mathrm{~m}$. During the survey the Meter was periodically checked with the $30 \mathrm{mph}$ and $45 \mathrm{mph}$ tuning forks to guarantee correct operation of Meter. 


\section{Procedure and Analyais}

The data from previous studies indicated that four locations In each clasalfication would provide a reasonable eatimate of average speeds at a moderate cost and consequentiy four of each type vere observed. Also, it vas previously indicated that 215 observations vould allow an estinate of the avorage passenger car apeeds within plus or ninus one mile per hour at a confidence level of $95 \%$.

Similarly, 35 observations of heavy trucks bere found to perait an estimation of average truck speeds within plus or alnus 2 alles per hour at a confidence level of $90 \%$. These mintmu sample sizes vere used for this study and consequently the average speeds recorded at the stations are estinates with posslble error and confidence as noted, of the true average speeds at these locatione under the existing conditions at the time of estimation. The speeds were recorded to the nearest mile per hour.

The vehiclee were classified as passenger car or truck. Passenger car data was further classiffed into two groups - Indiana or out-of-state and the analysis was performed aingly and combined. The trucks were also classified 1nto two groups - 11ght (1ess than 5000 pounds gross weight) or heavy (more than 5000 pounds gross weight) and the analyais was performed aingly and coubined. The data were recorded and analyzed in the above manner to compare Indiana and out-of-state observed speeds with legal speeds and the observed truck speeds with the legal speed according to weight classificatioa. The speed 1 inits in Indiana are as follows: 65 afles per hour for passenger cars and light trucks; 55 mlles per hour for heavy trucks on divided highways with a median width of 20 feet or 
more and 50 miles per hour for heavy trucks on other h1ghways. All four lane and interatate highways observed in this study were divided by a median at least 20 feet in width. 


\section{Symary and Results}

The date collected at each observation station are sumarized by station in Tables 1 through 12 and by type of facility - interstate, four-lane, two-lane - in Tables 13 through 15 . Table 16 is a sumnary of all the data collected. Figures 1 through 16 are cumulative frequency curves computed and dram from each of the corresponding tables. Speed trend data for the past few years are tabulated in Table 17 and shown graphically in Pigure 17.

From Table 17 and Figure 17 it 1 s apparent that speeds have increased and leveled off over the last ten years. Although there appears to be a general incrcase of 1 mph on all facilities since last year, this may be due to an inconsistency between the last and present observer and the general leveled trend may actunliy be continuing. The 85th percentile speed has also shown an apparent stabilization during recent years. The figures show an 85 th percentile speed of approximately $66 \mathrm{mph}$ for four-lane and interstate facilities and 64 mph for two-lane facilities. This is of interest when corapared with the permissible top speed of 65 mph allowed on Indiena roads.

Truck speeds have shown a decrease in speeds in comparison with the previous year's figures. These results when viewed in 11ght of a general increase in passenger car speeds in the last year are difficult to analyze. This may again be due to an observer's inadequacy or may be the beginning of a stabllizing trend in the previously slowly increasing speeds. Future observations will have to be closely watched to decide if a trend has been established.

A comparison of the observed and allowable speed of the heavy trucks, produces the following information: 


$\begin{array}{lcccc}\text { Iype } & \begin{array}{c}\text { 85th percentile } \\ \text { speed }\end{array} & \begin{array}{c}\text { Speed } \\ \text { 11mit }\end{array} & \begin{array}{c}\text { \% traveling at } \\ \text { less than the } \\ \text { speed 11mit }\end{array} & \begin{array}{c}\text { \% traveling at } \\ \text { speeds greater } \\ \text { than the 1imit }\end{array} \\ \text { Interstate } & 56.8 & 55 & 72.8 & 27.2 \\ \text { Four-lane } & 53.4 & 55 & 90.1 & 9.9 \\ \text { Two-lane } & 53.1 & 50 & 68.1 & 31.9\end{array}$

From this it can be seen that approximately $30 \%$ of the heavy trucks are speeding on Interstate and two-lane facilities. Bowever, further analysis will show that on Interstate facilities approximately half the speeders are in excess by less than $2 \mathrm{mph}$ and on the twolane facilities approximately half the speeders are in excess by less than 3 mph. This would seem to indicate that the problem is not as severe as the tabulated values may suggest.

of particular interest is the simflarity in characteristics between travel on four-lane and interstate facilities. The meanspeeds, 85th percentile and 15th percentile speeds for both facilities are practically the same. This is probably accounted for by the fact that the four-lane highways observation stations are so located as to present similar roadway conditions to those found in the interstate systen - that 1s, good shoulder; wide medians; 11ttle access friction. 


\section{Reconmendations}

It is recoumended that the general procedure of using four stations of each type facility and a sample size of 215 passenger cars and 35 trucks be continued. However, it is further recomended that certaln specific refinenents be nade to allow a better compar1son of consecutive yearly data. These axe as follows:

1) A better systen of identification of each of the observation sites to guarantee use of the same site each year.

2) The sinultaneous recording of a volube count at the observation site to compare speed variations and the change in volumes at the times of observation. 


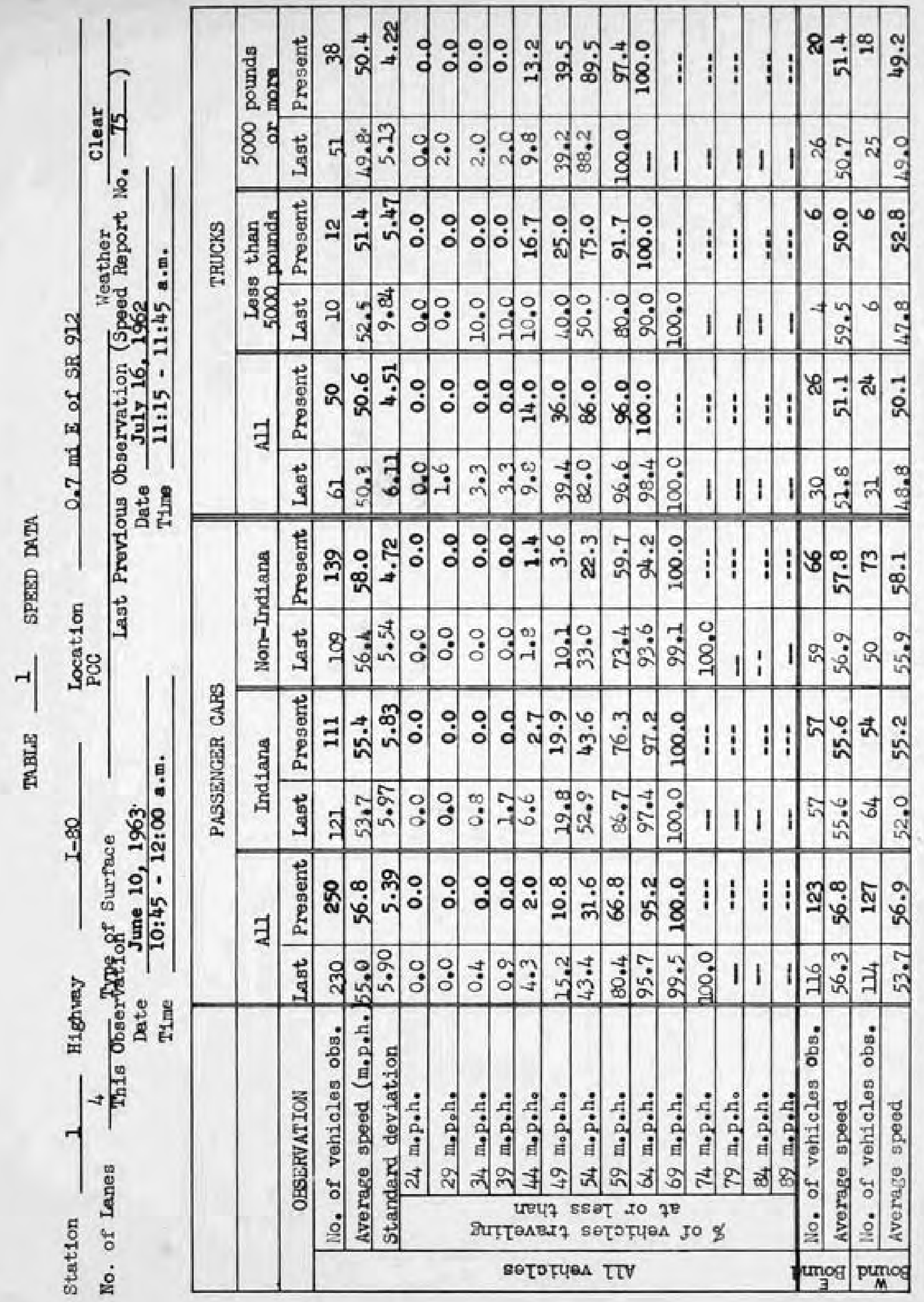




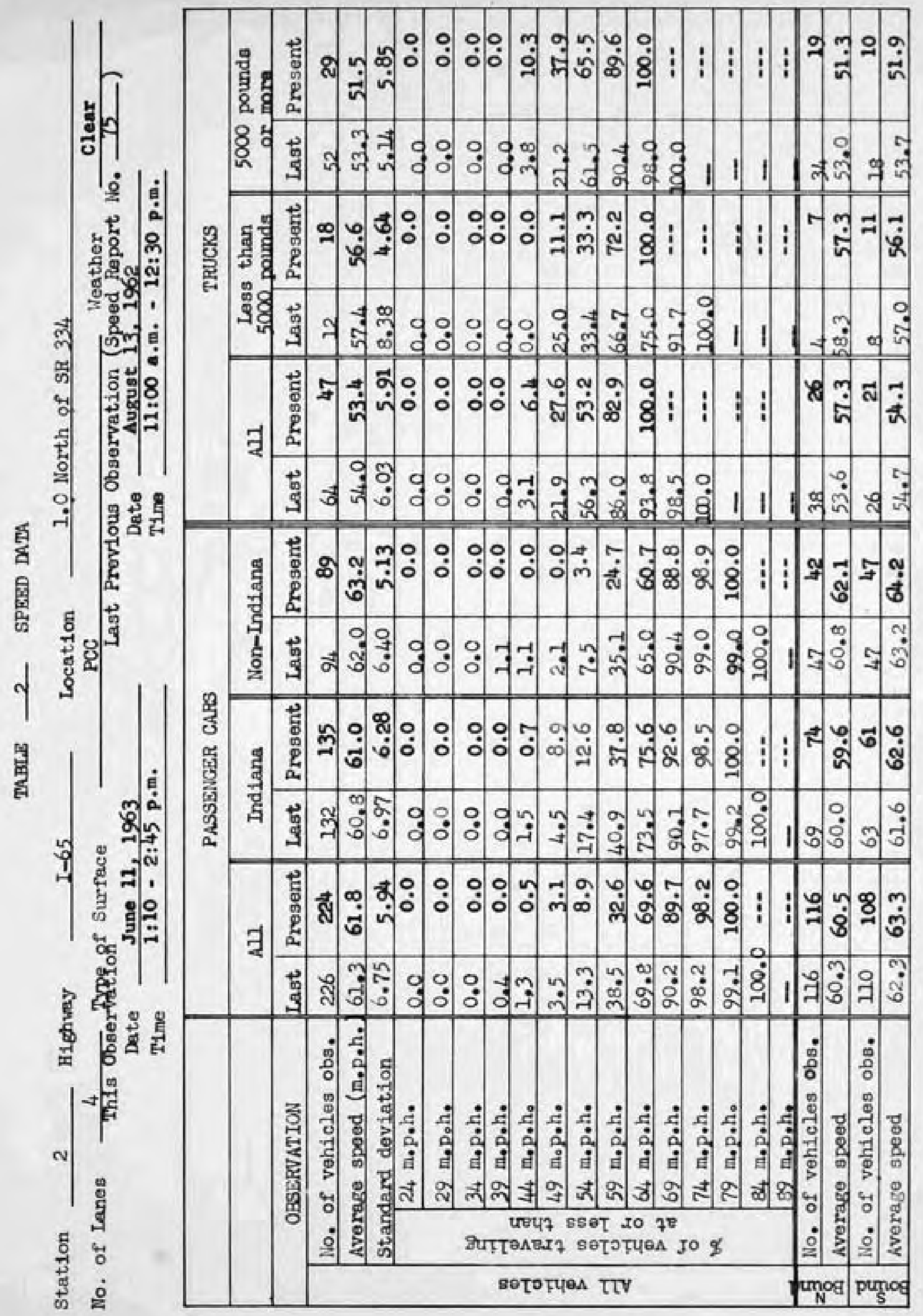




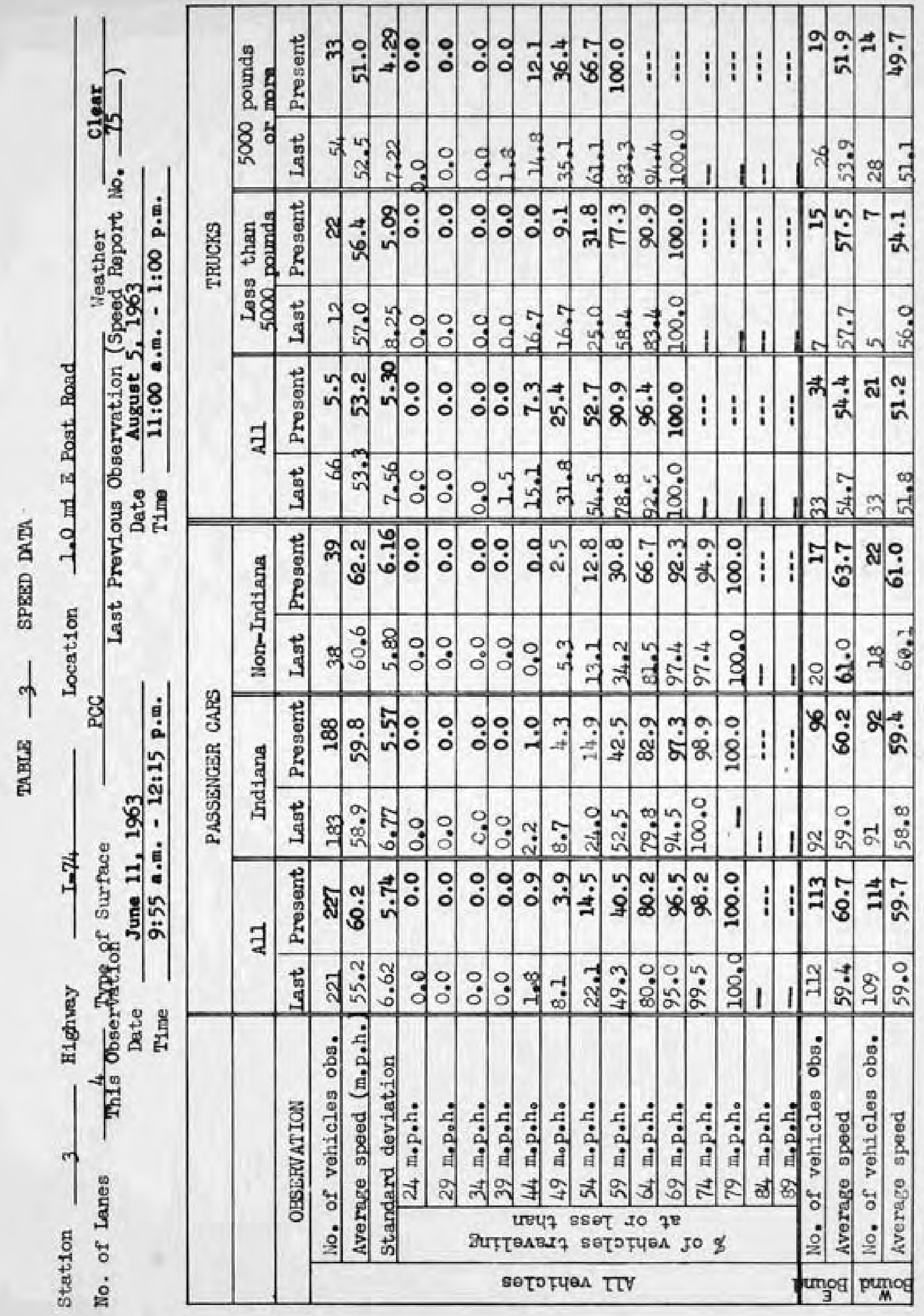




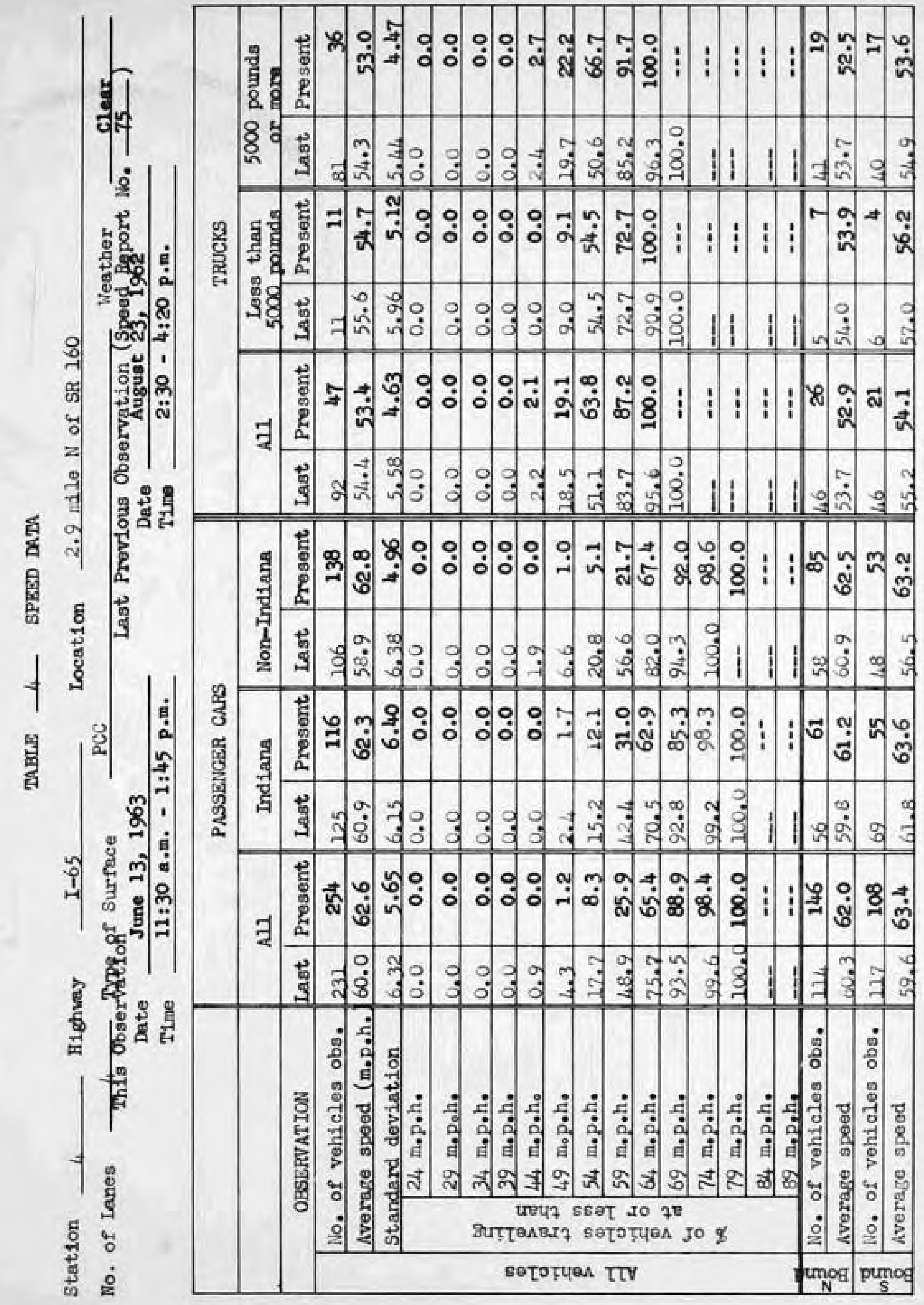




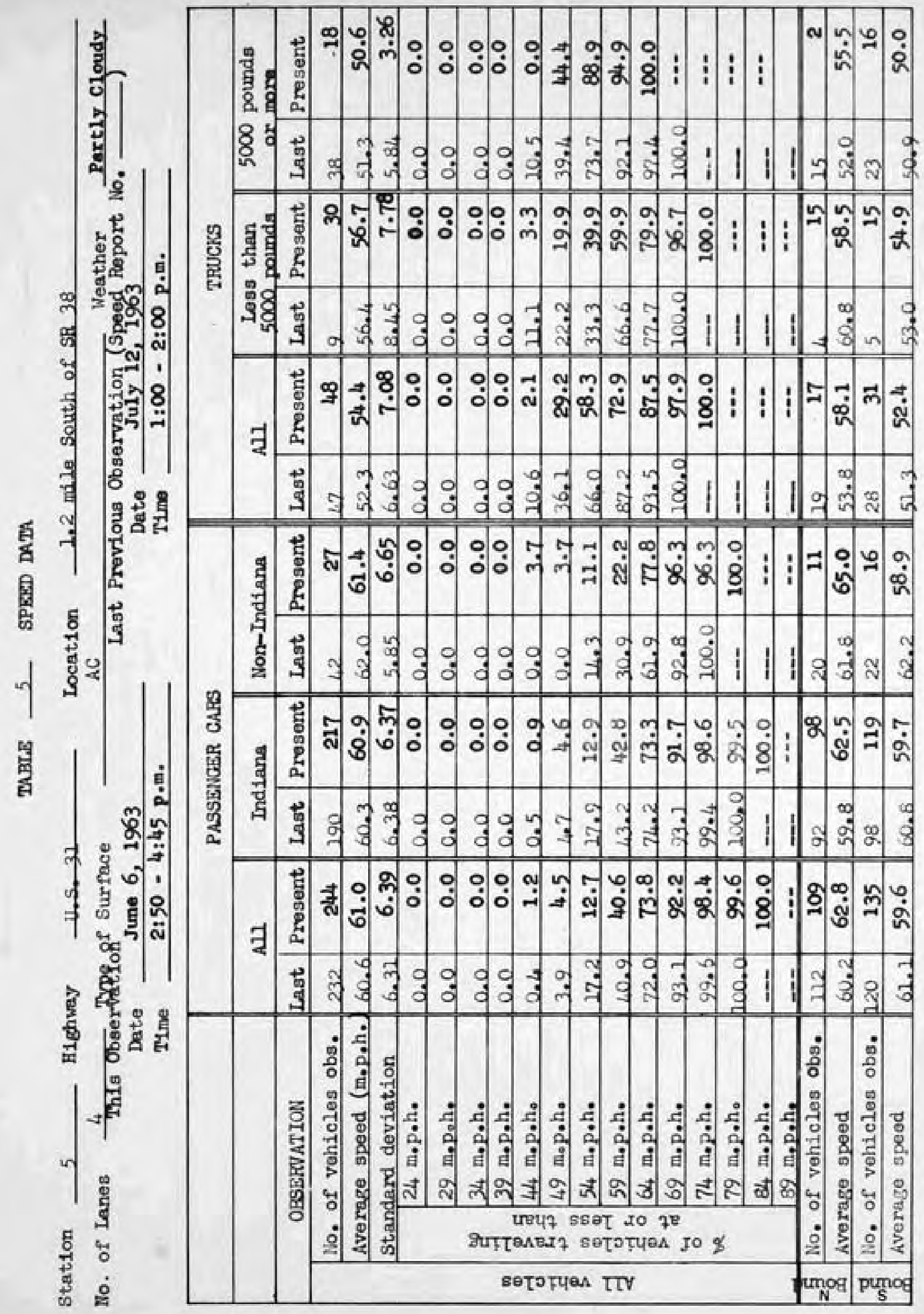




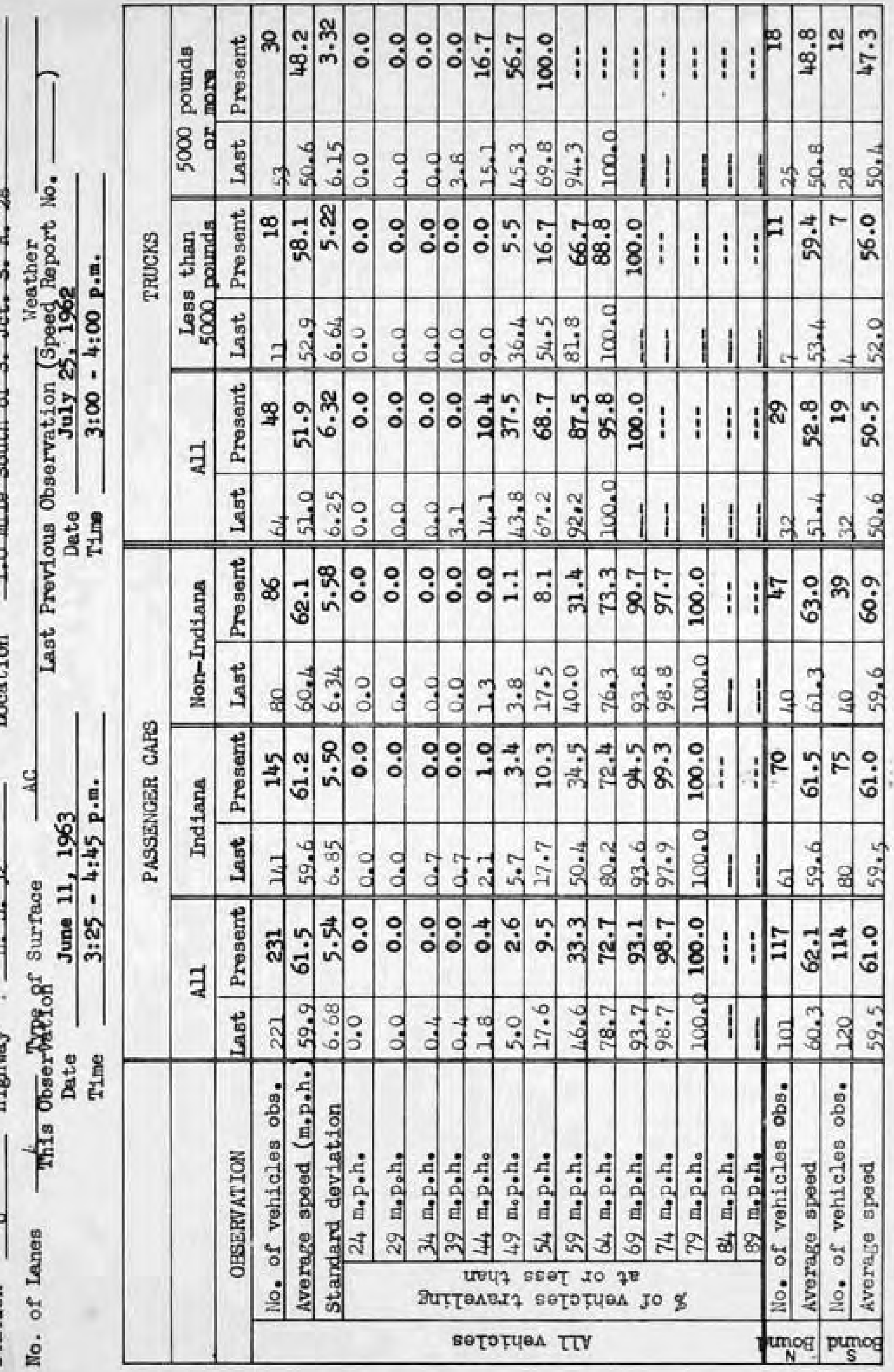




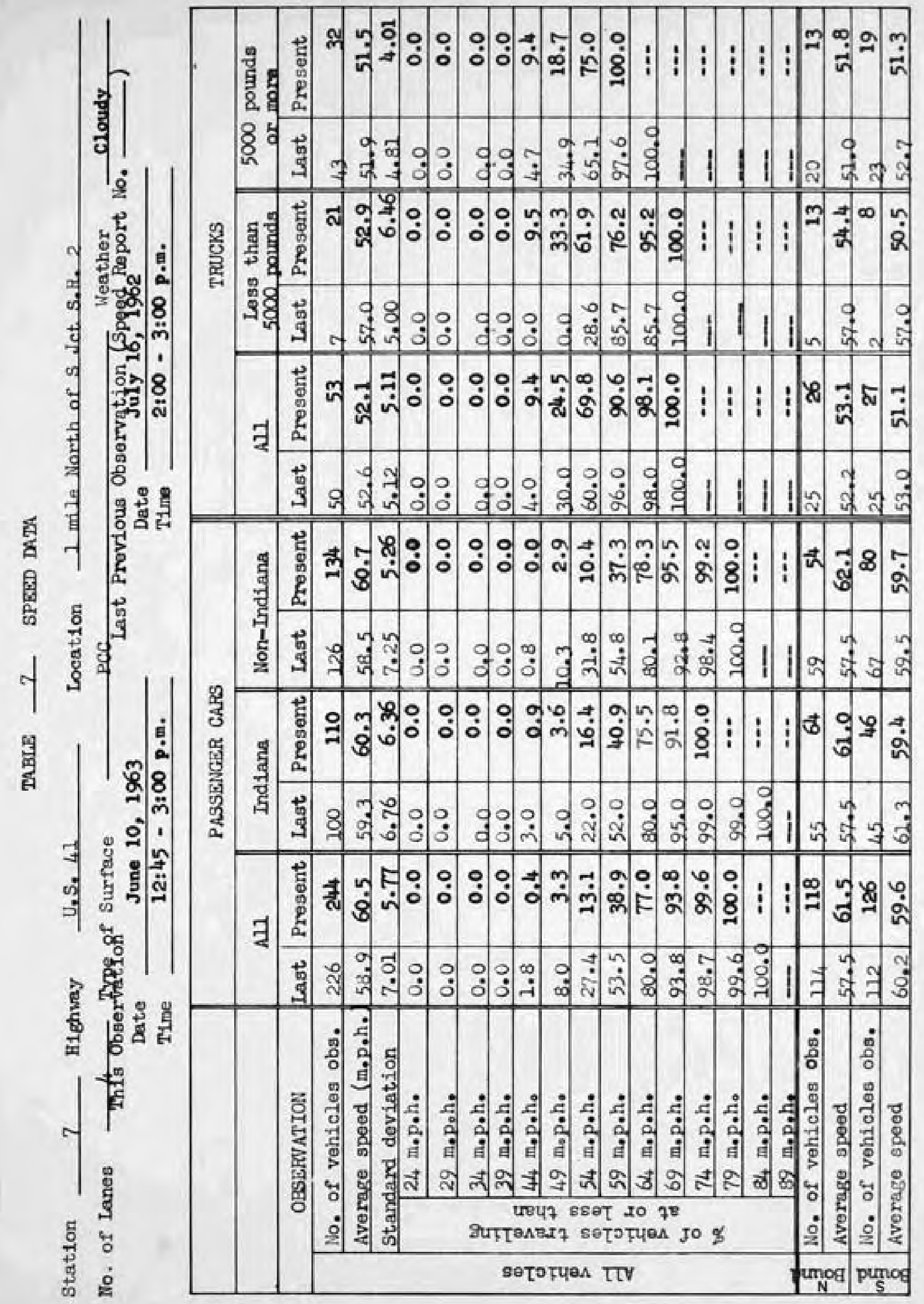




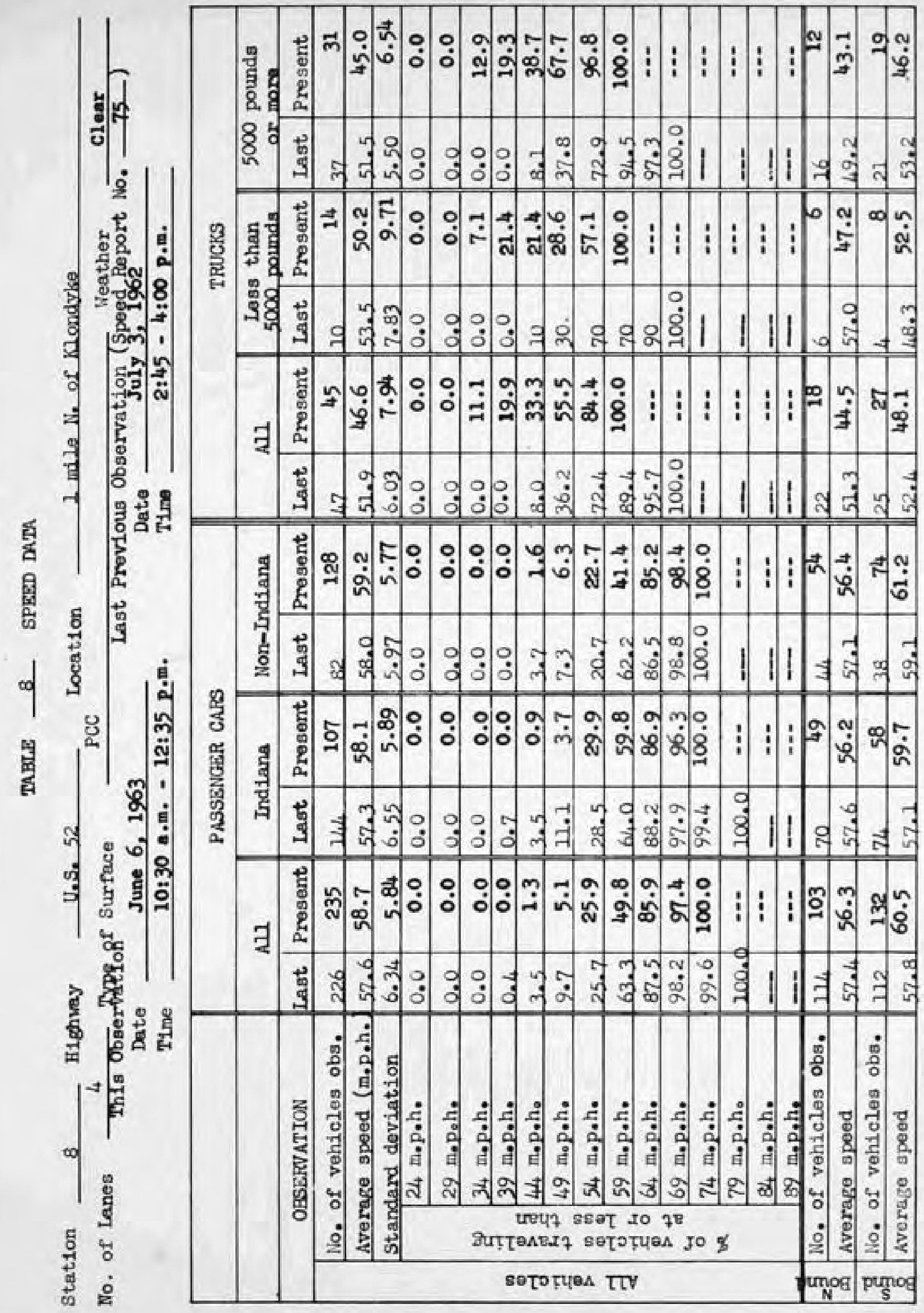




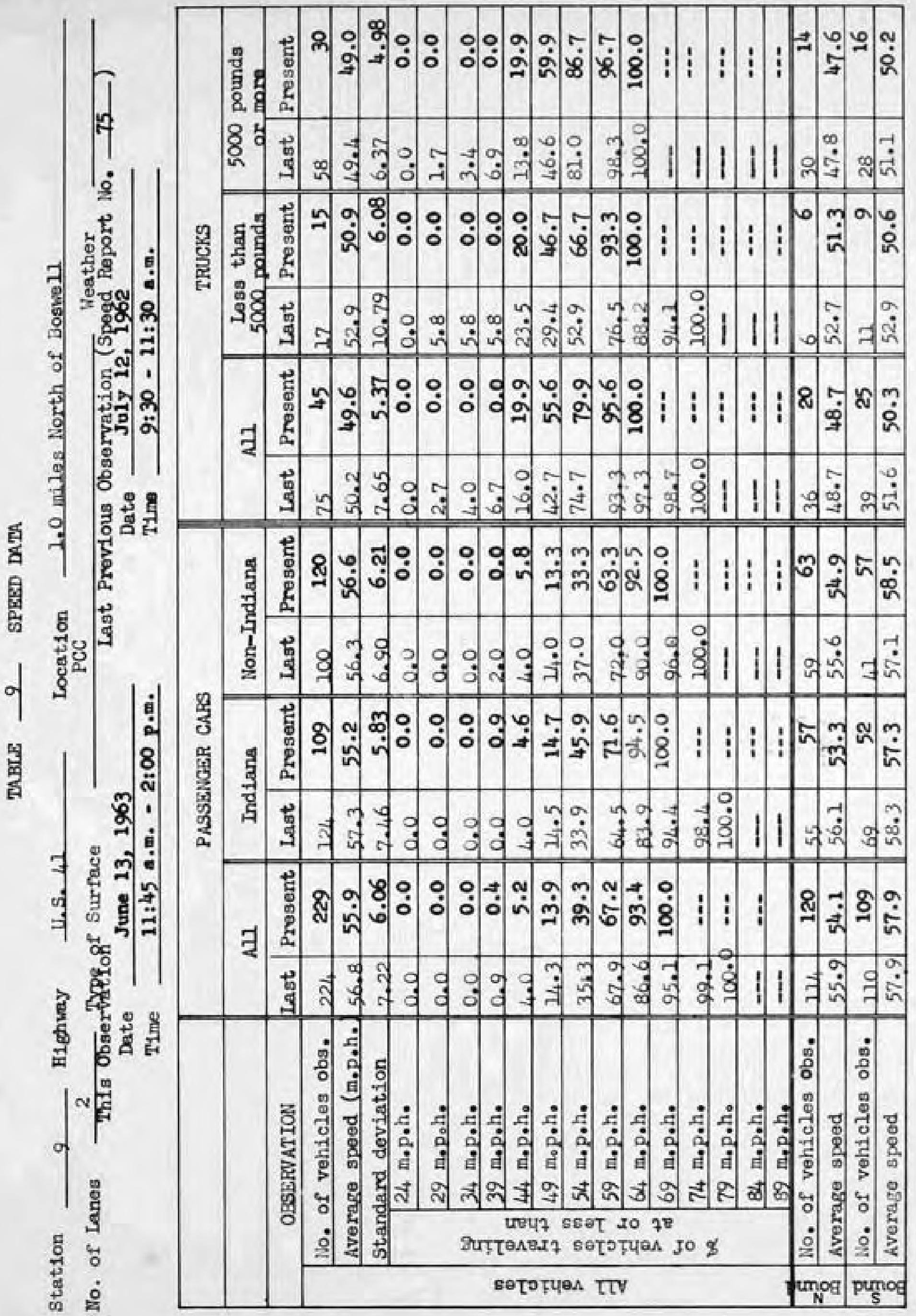




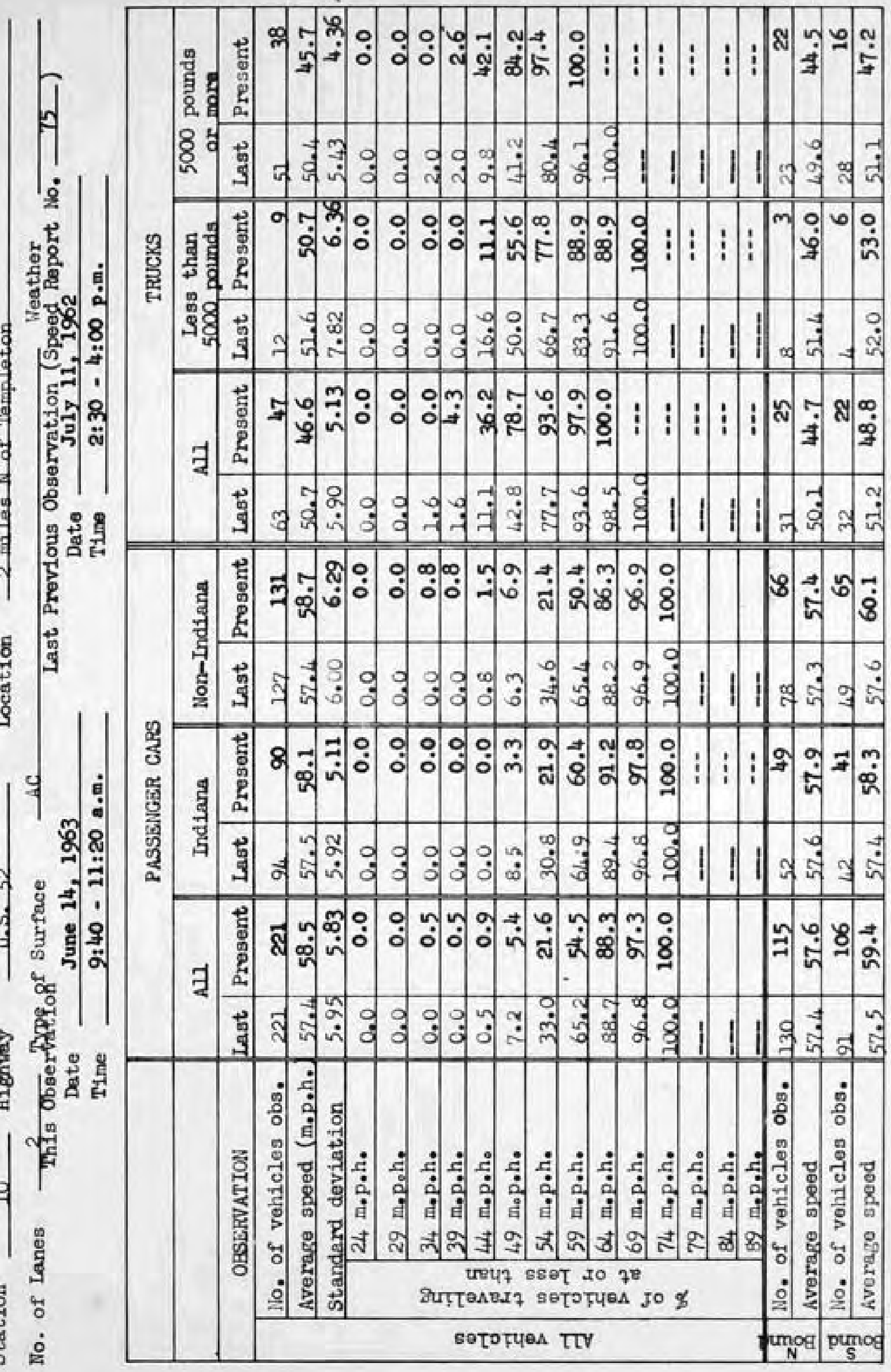




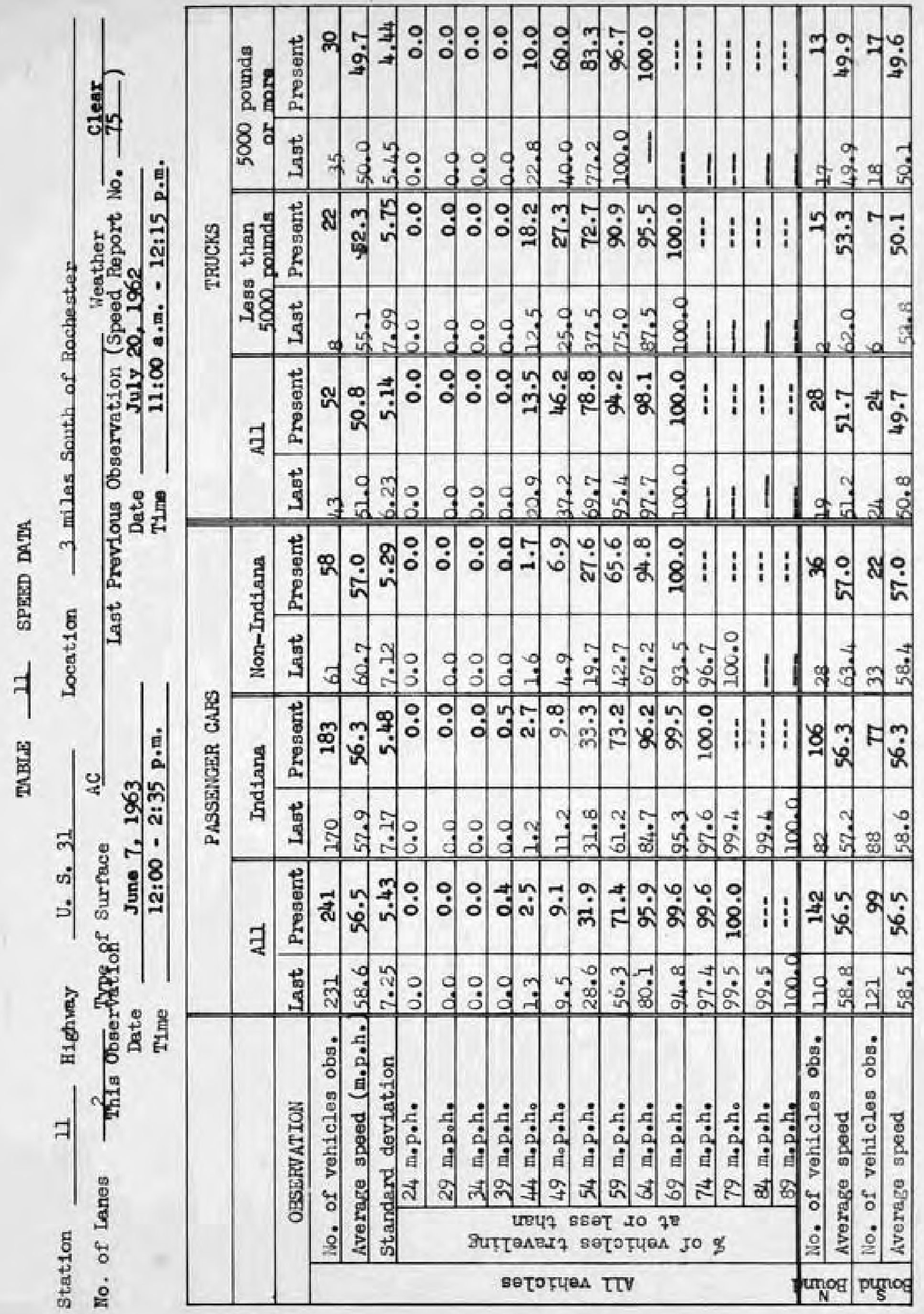




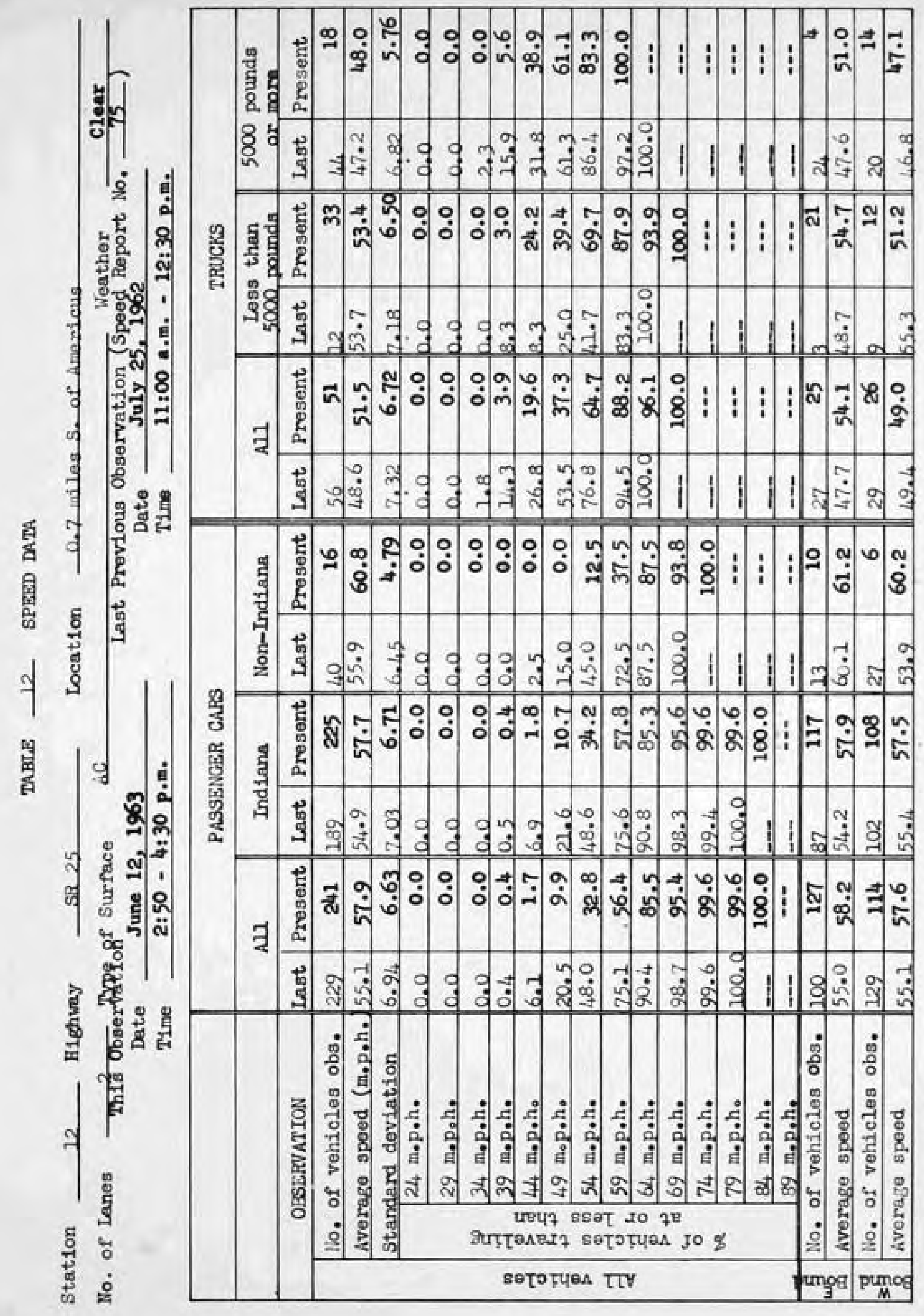




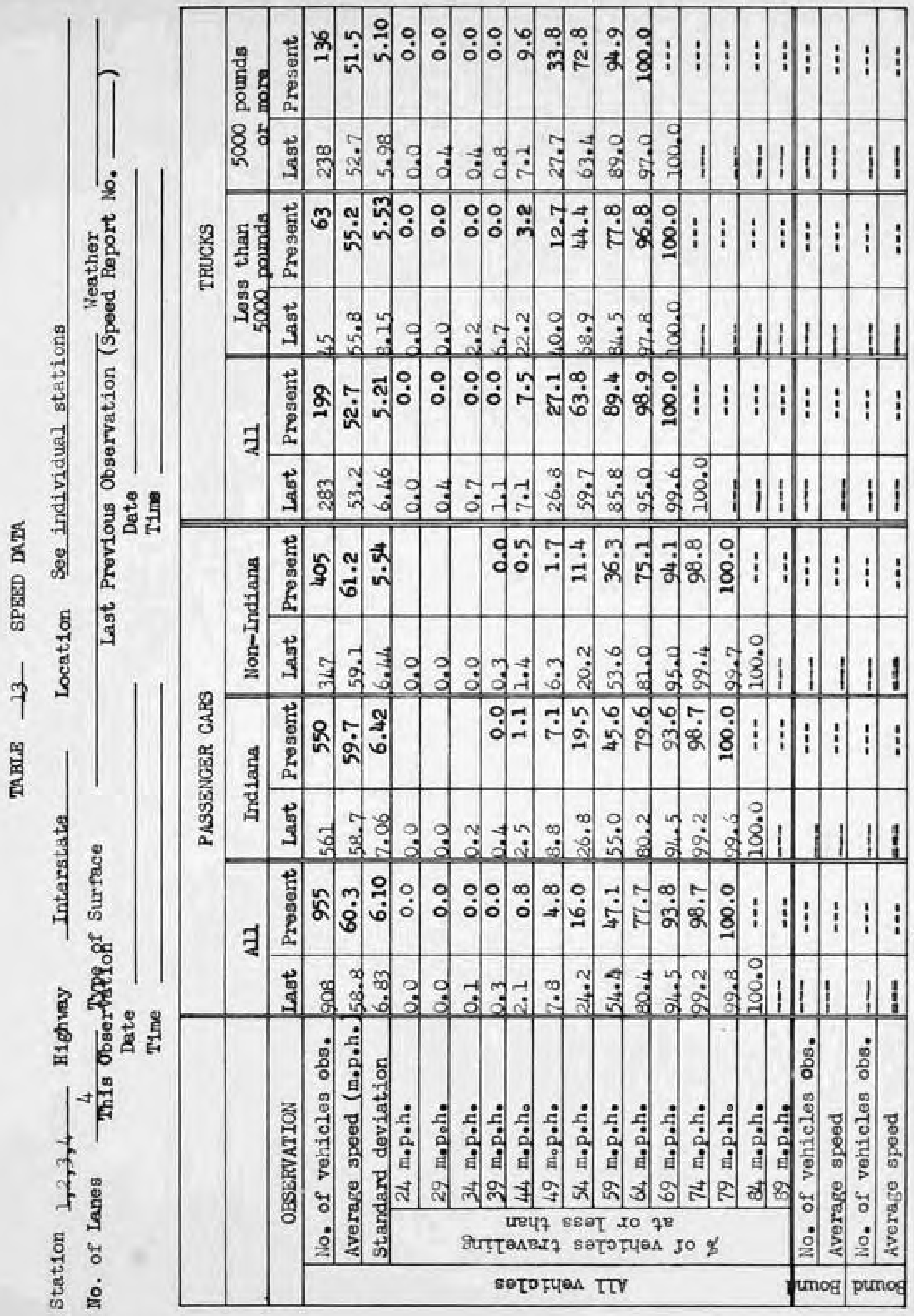




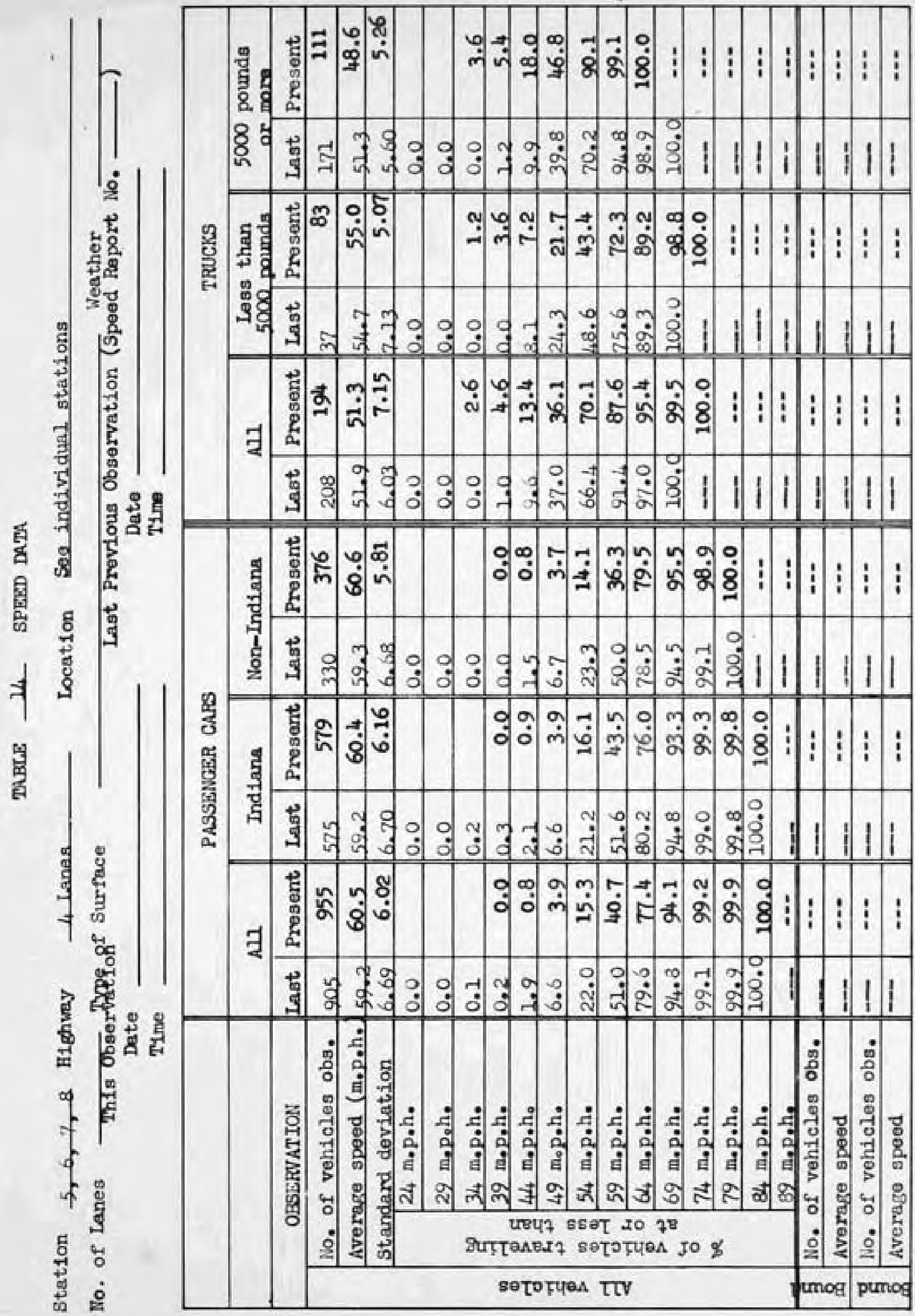




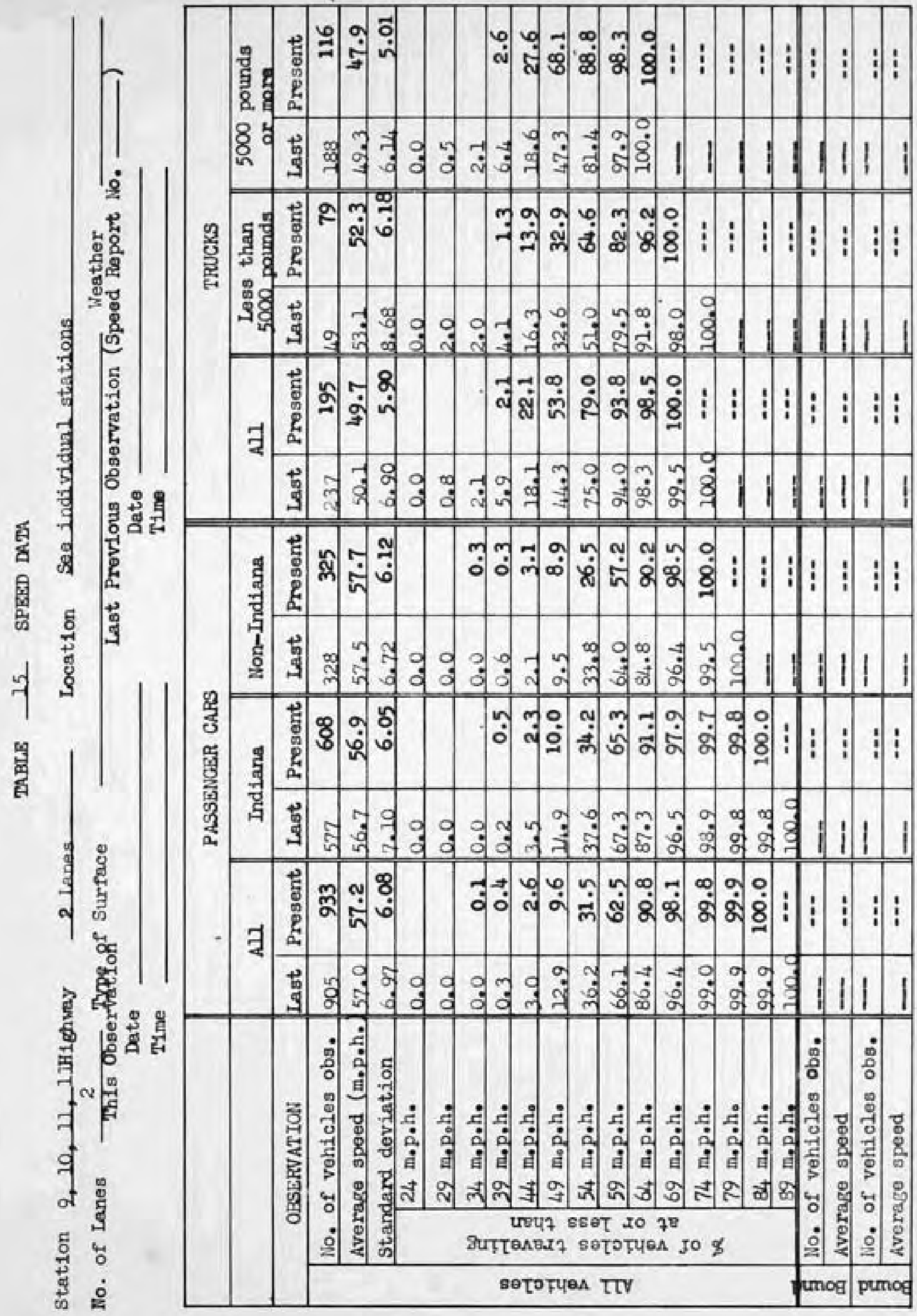




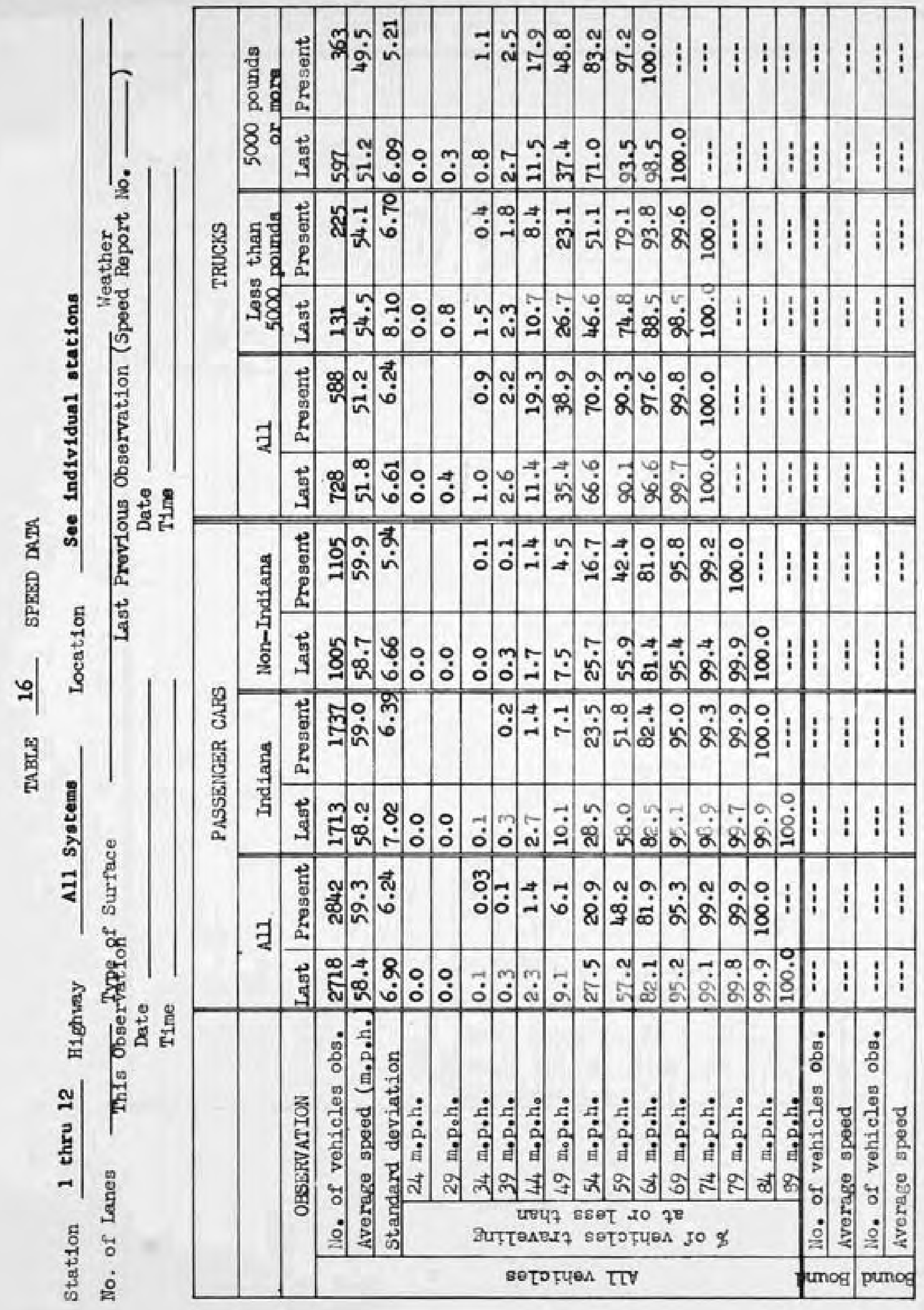




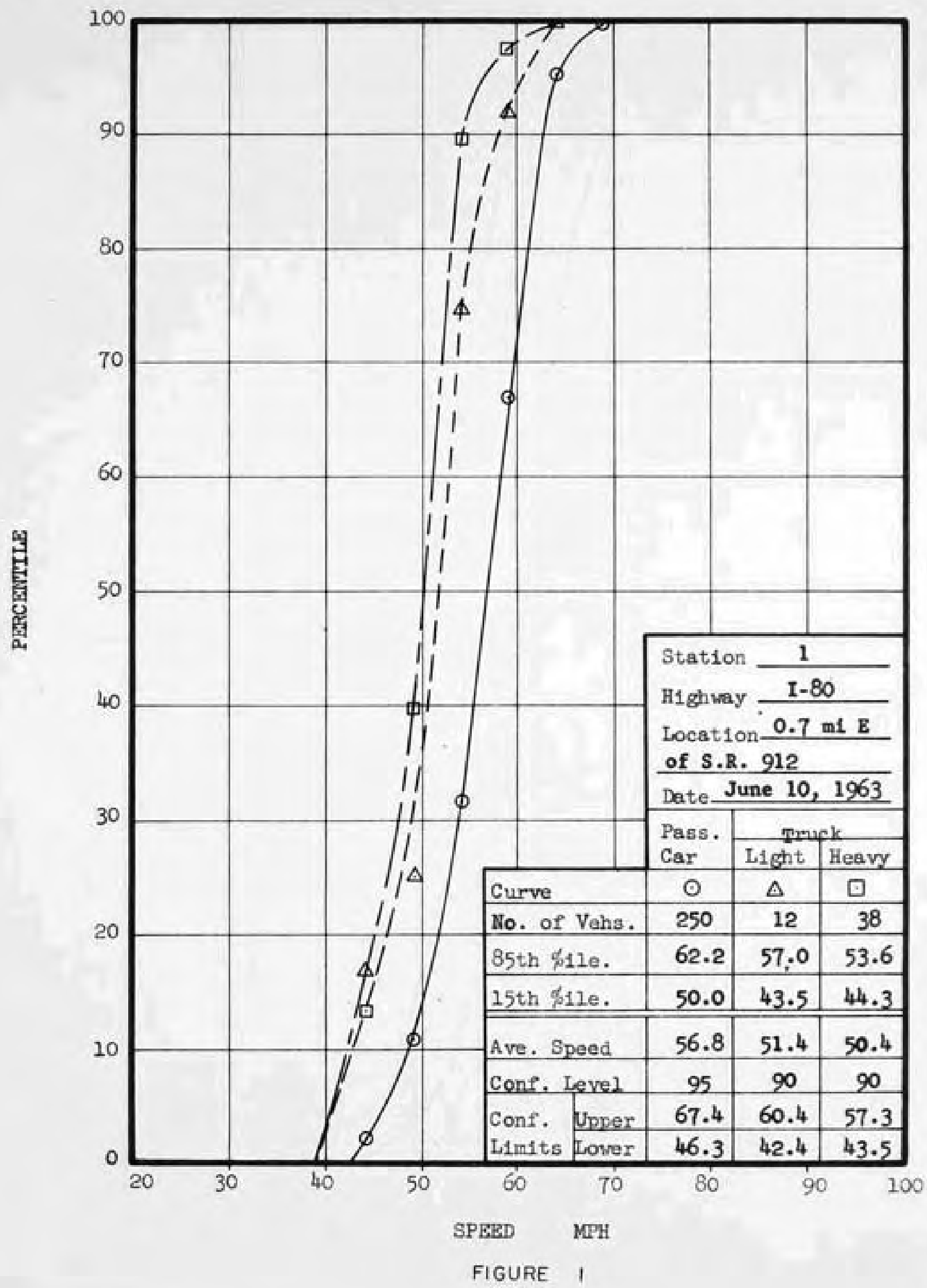




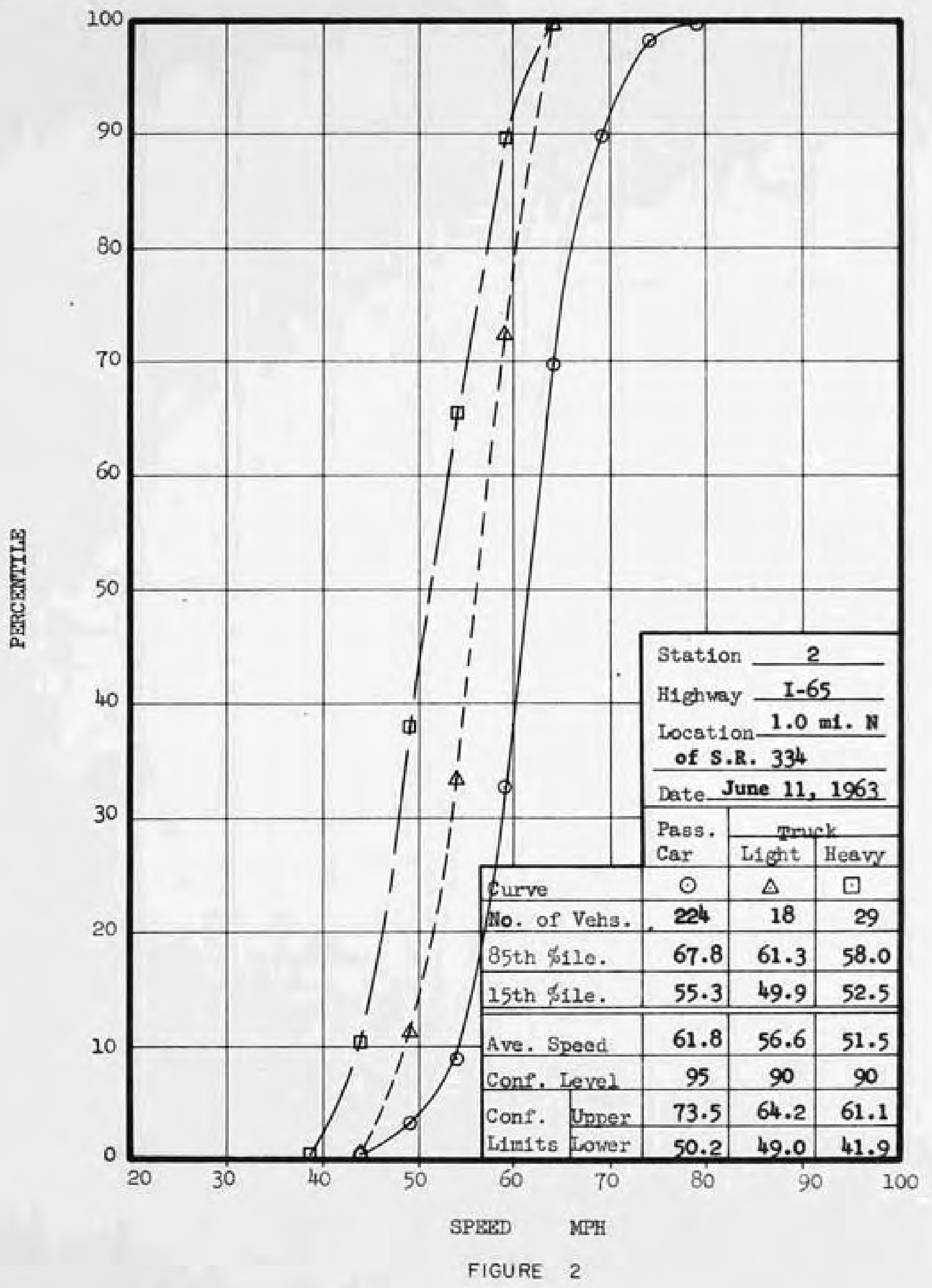




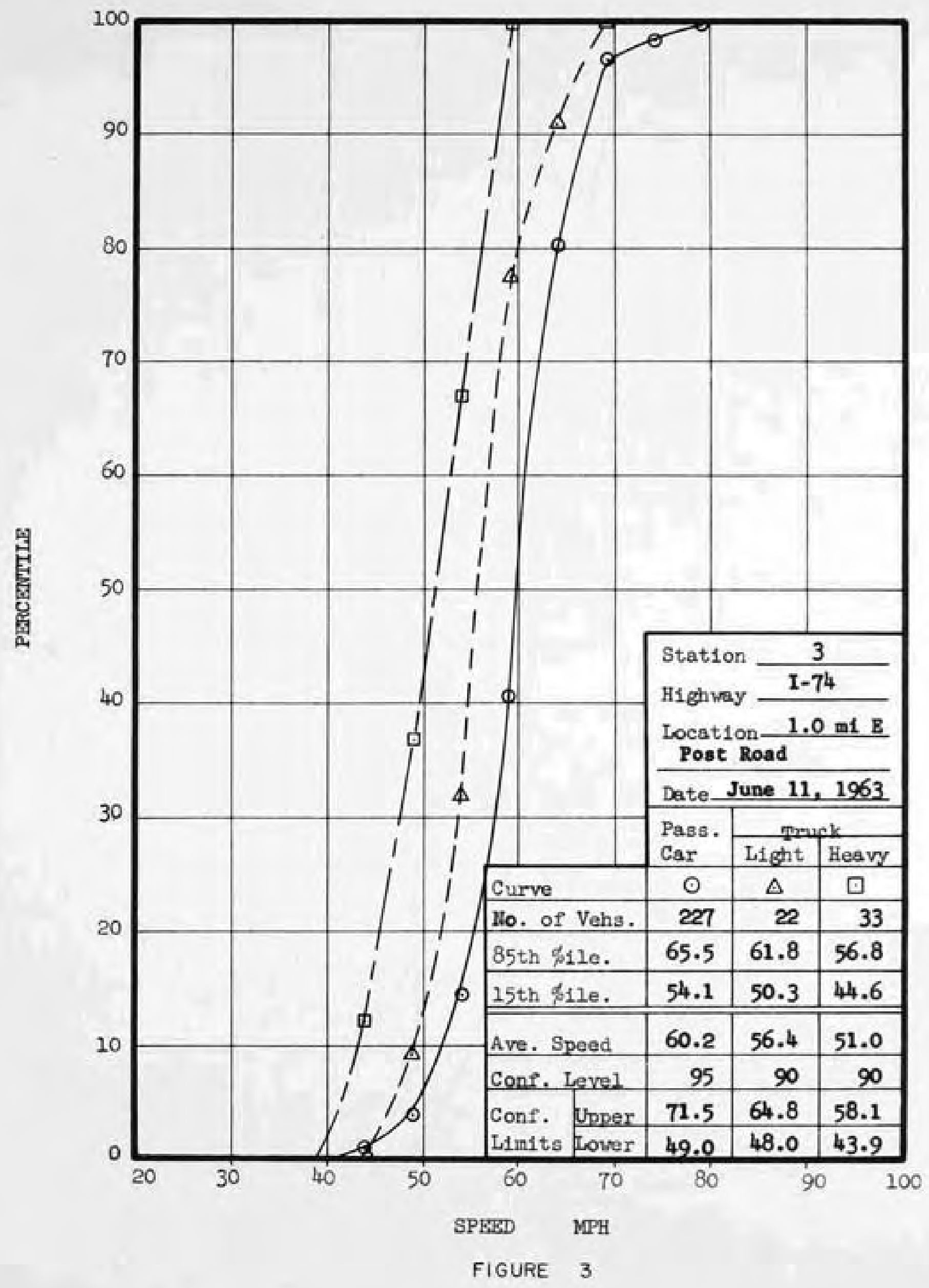




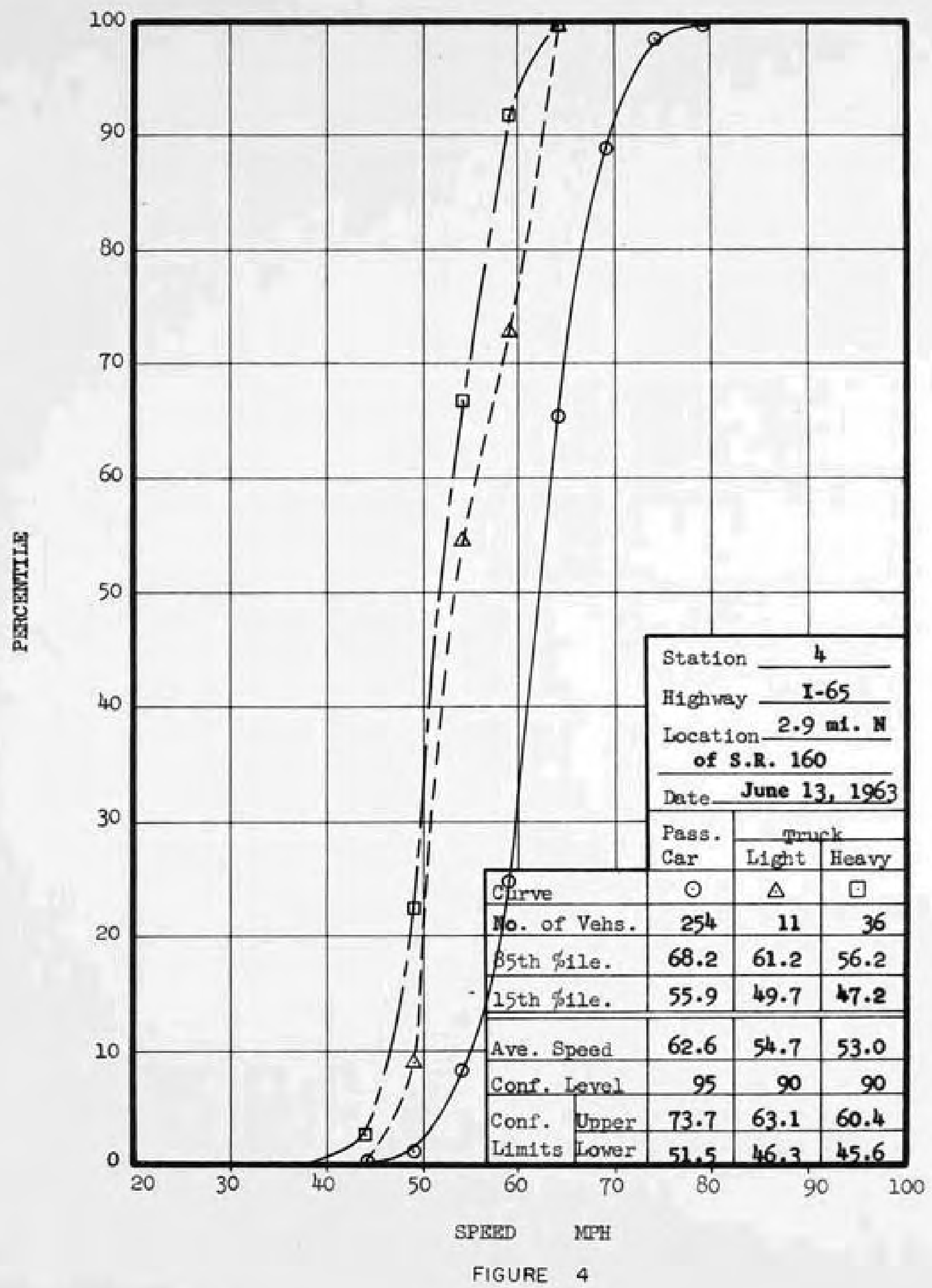




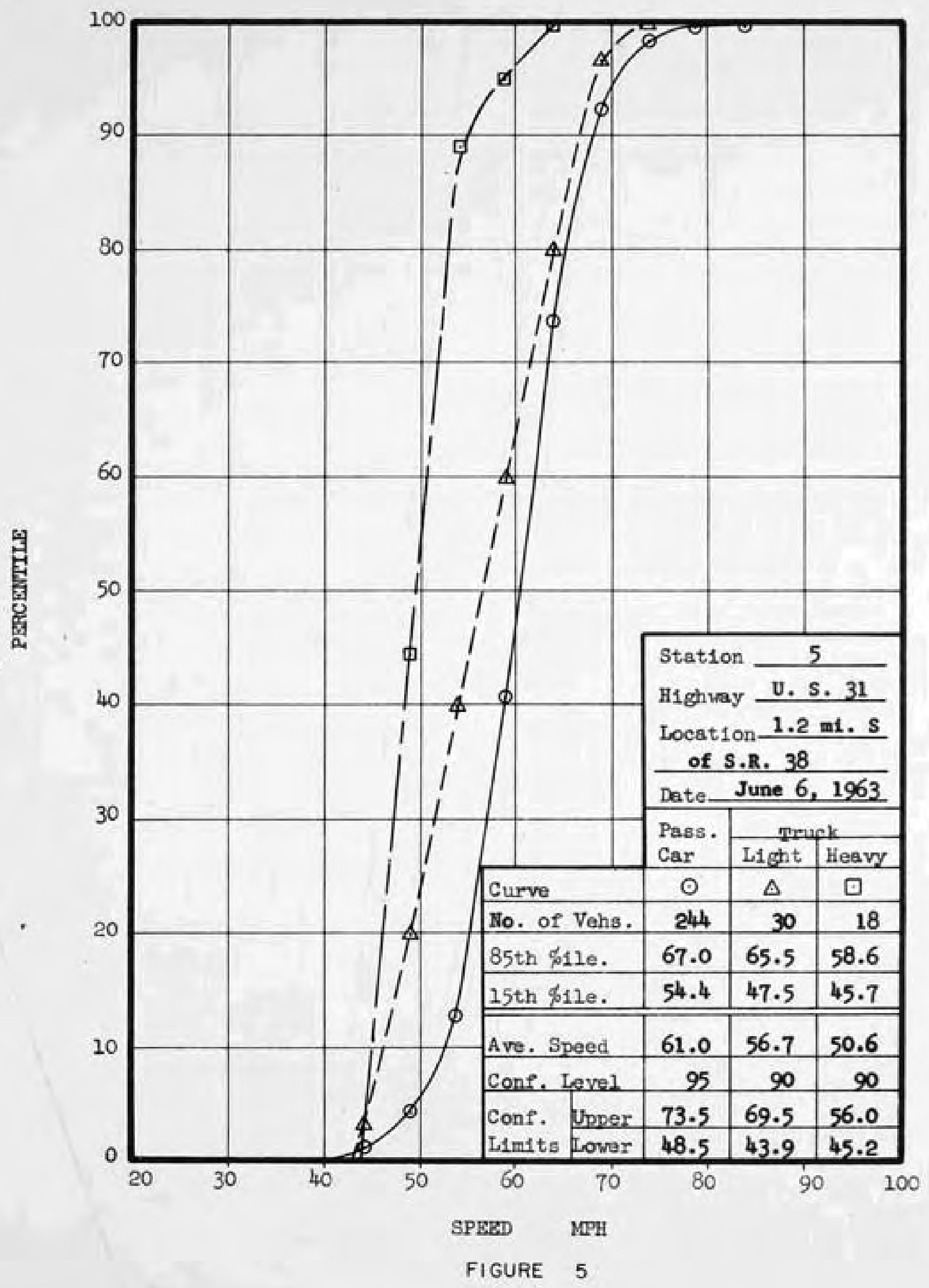




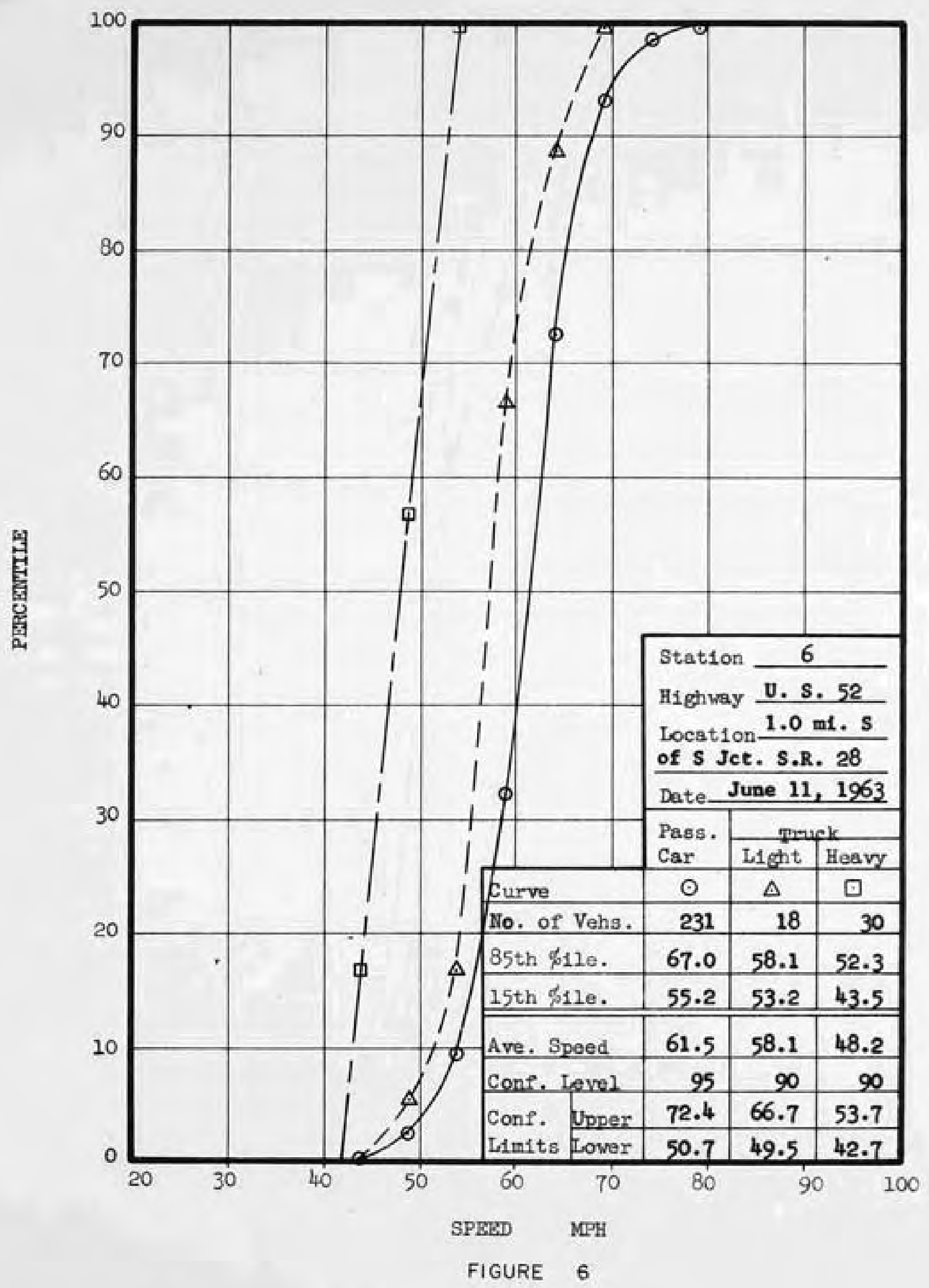




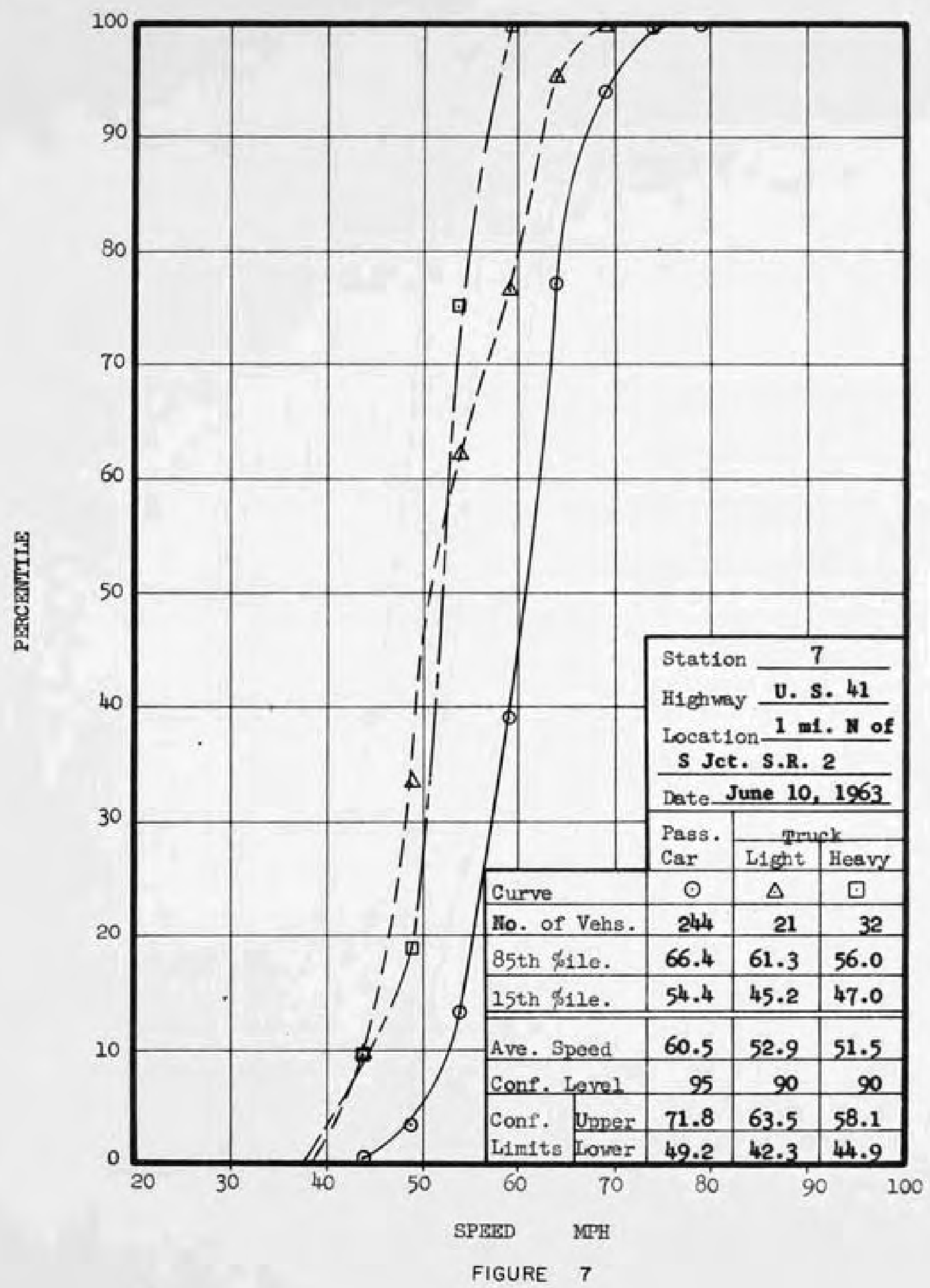




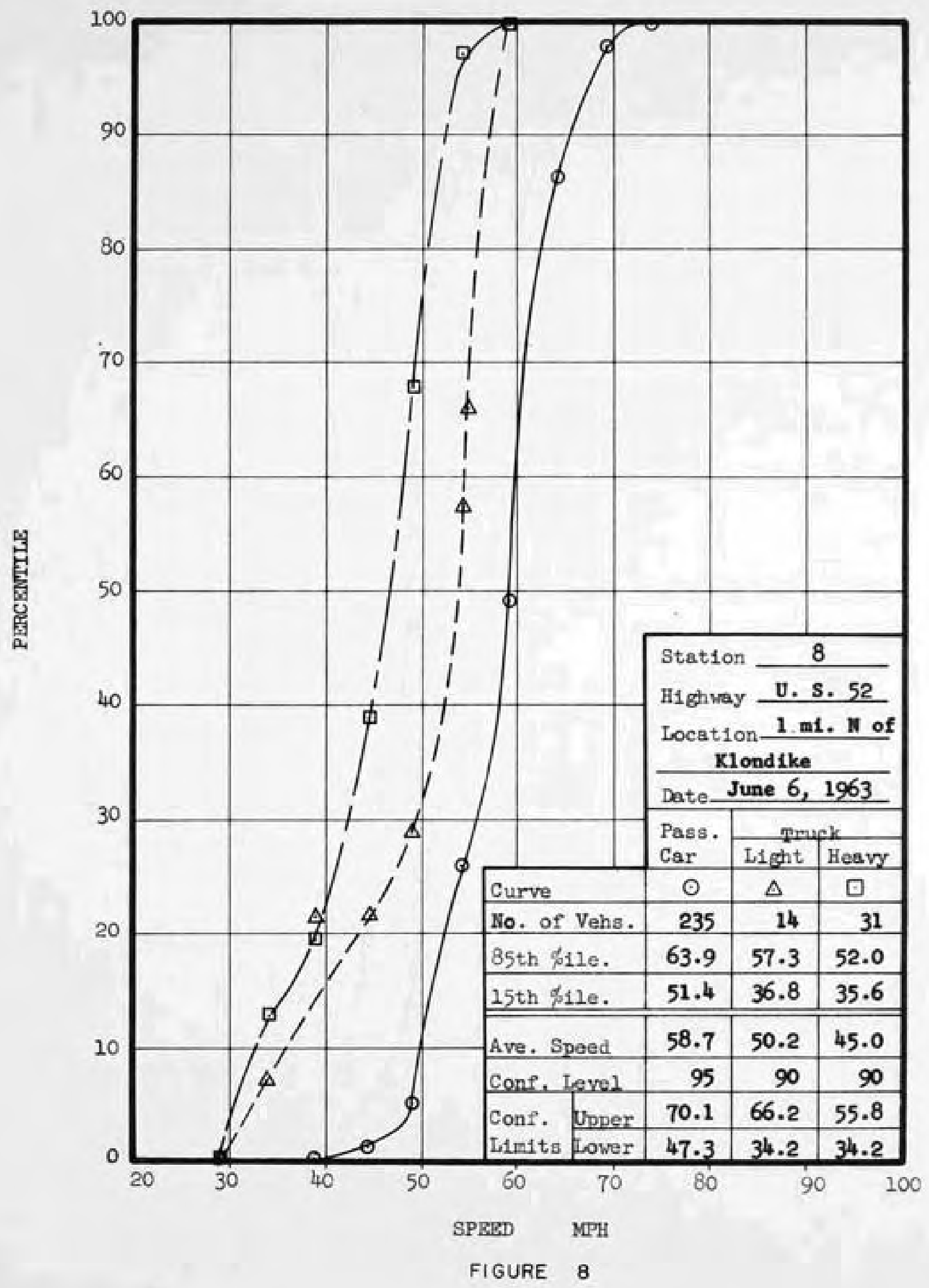




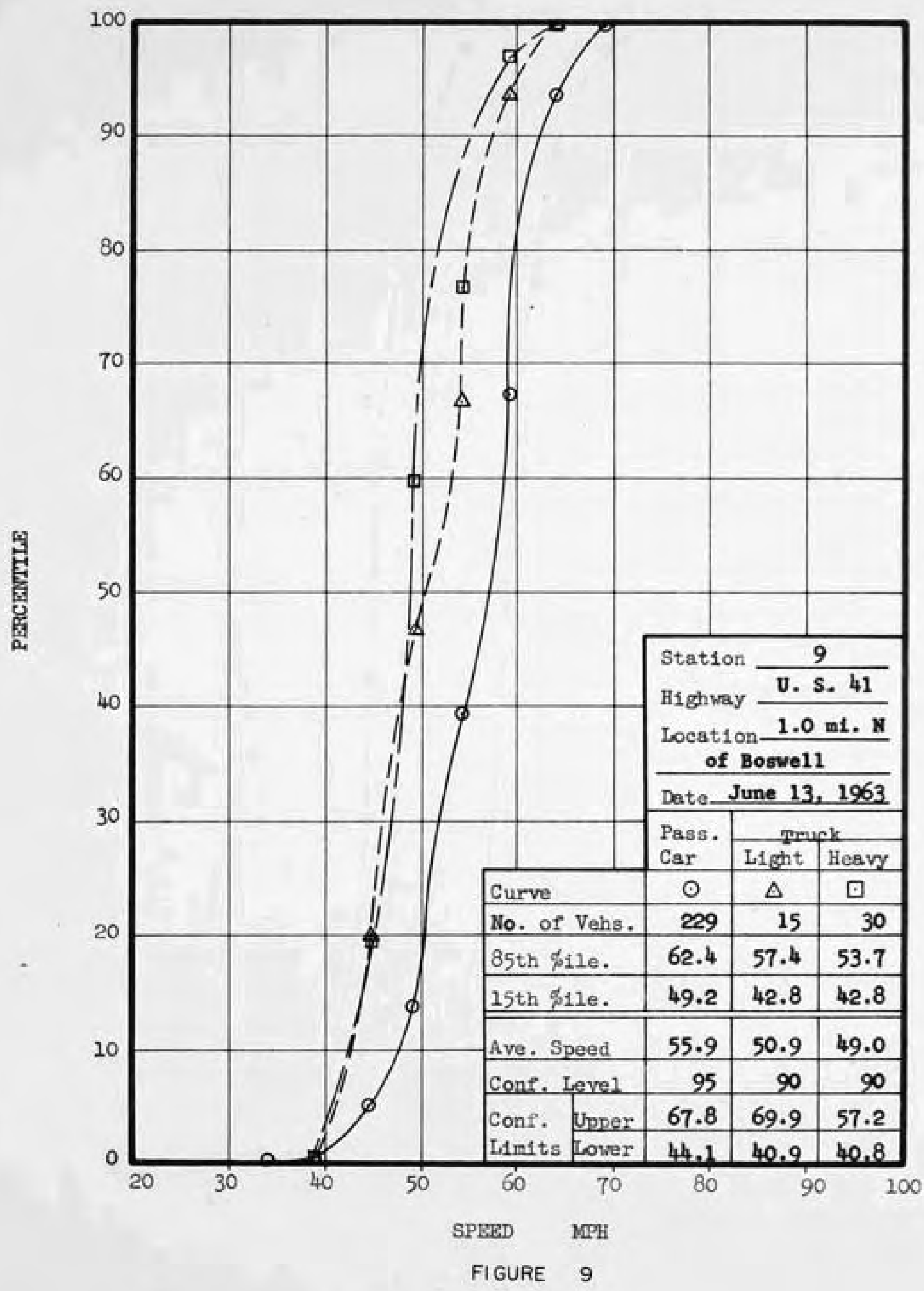




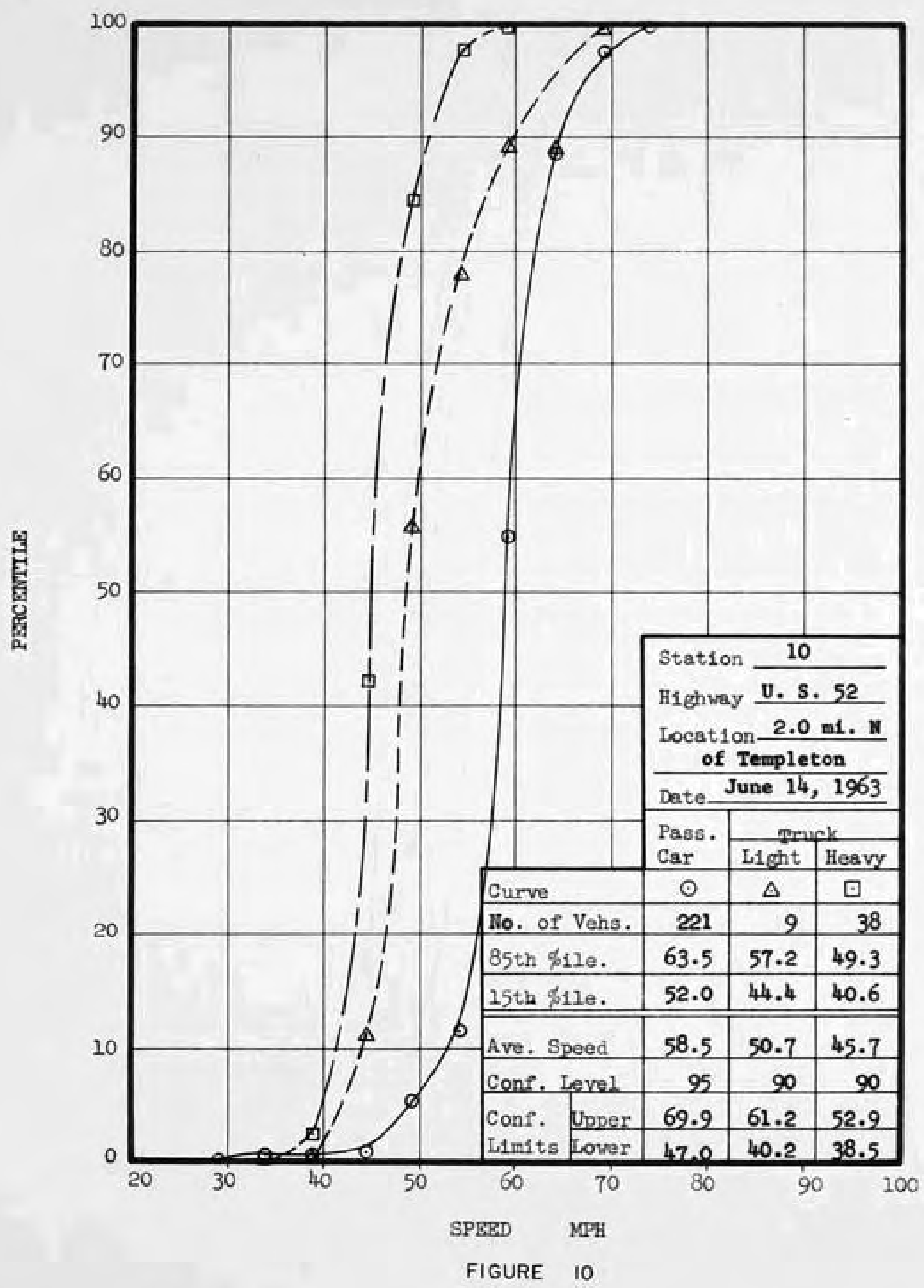




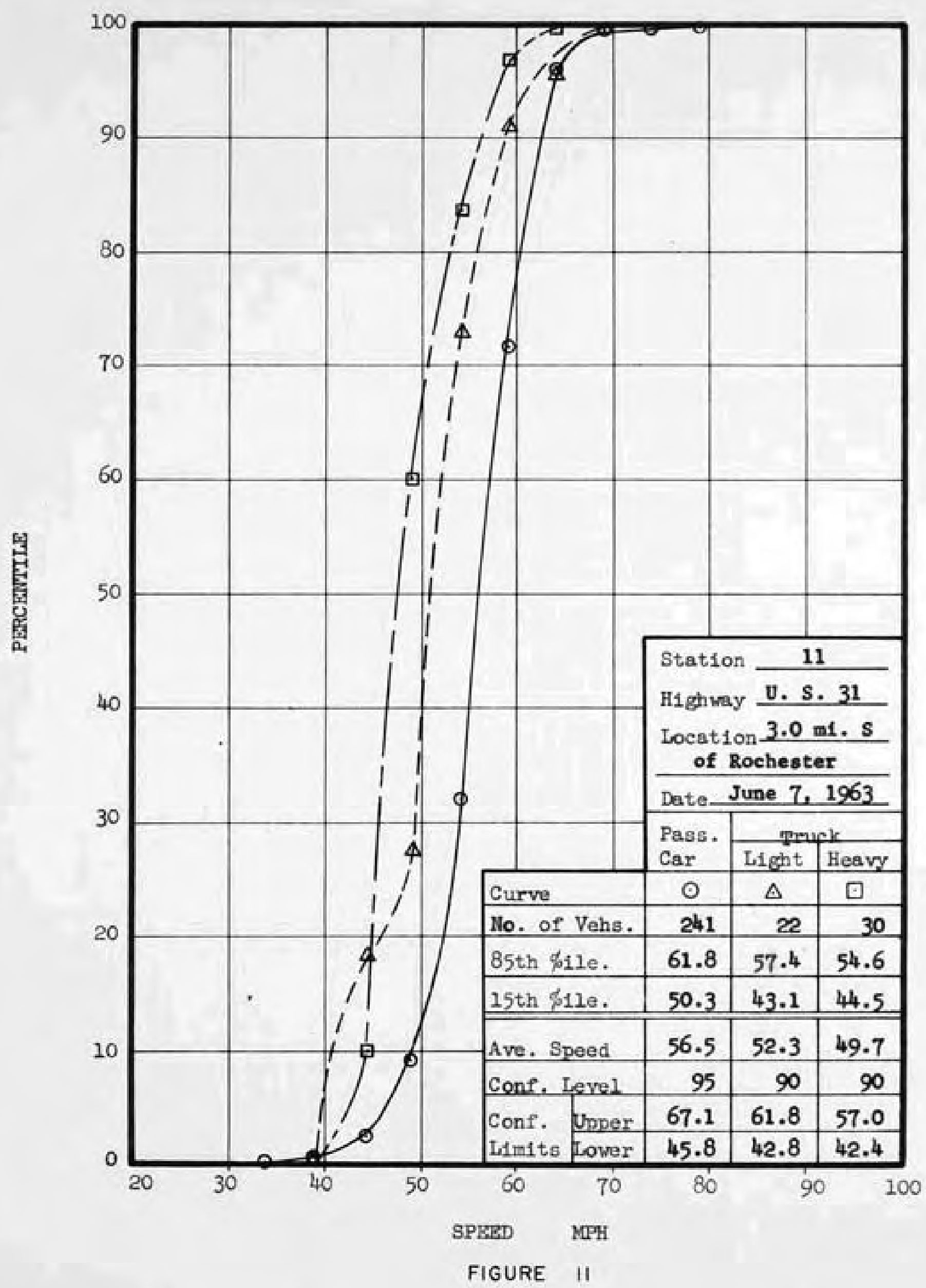




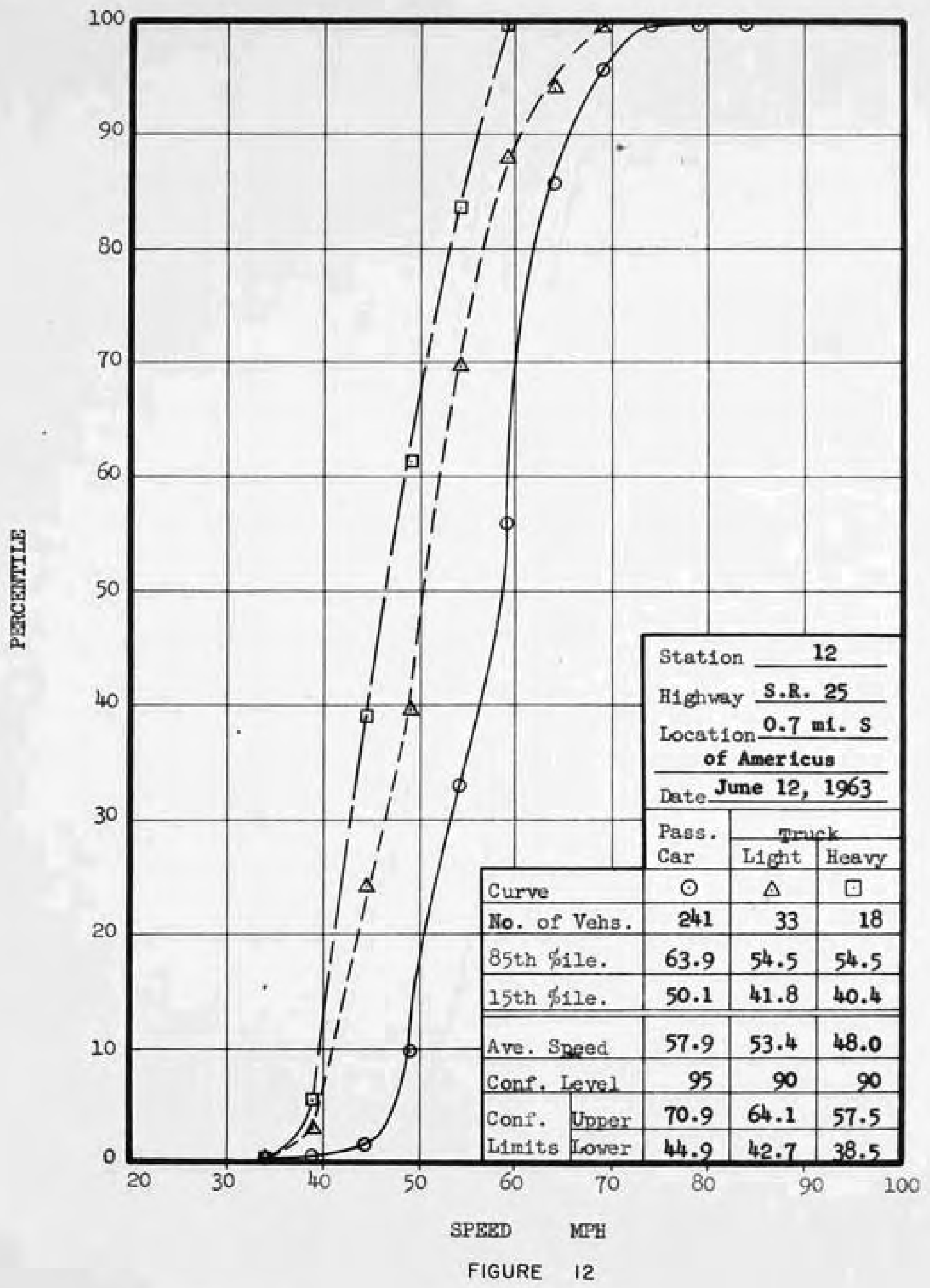




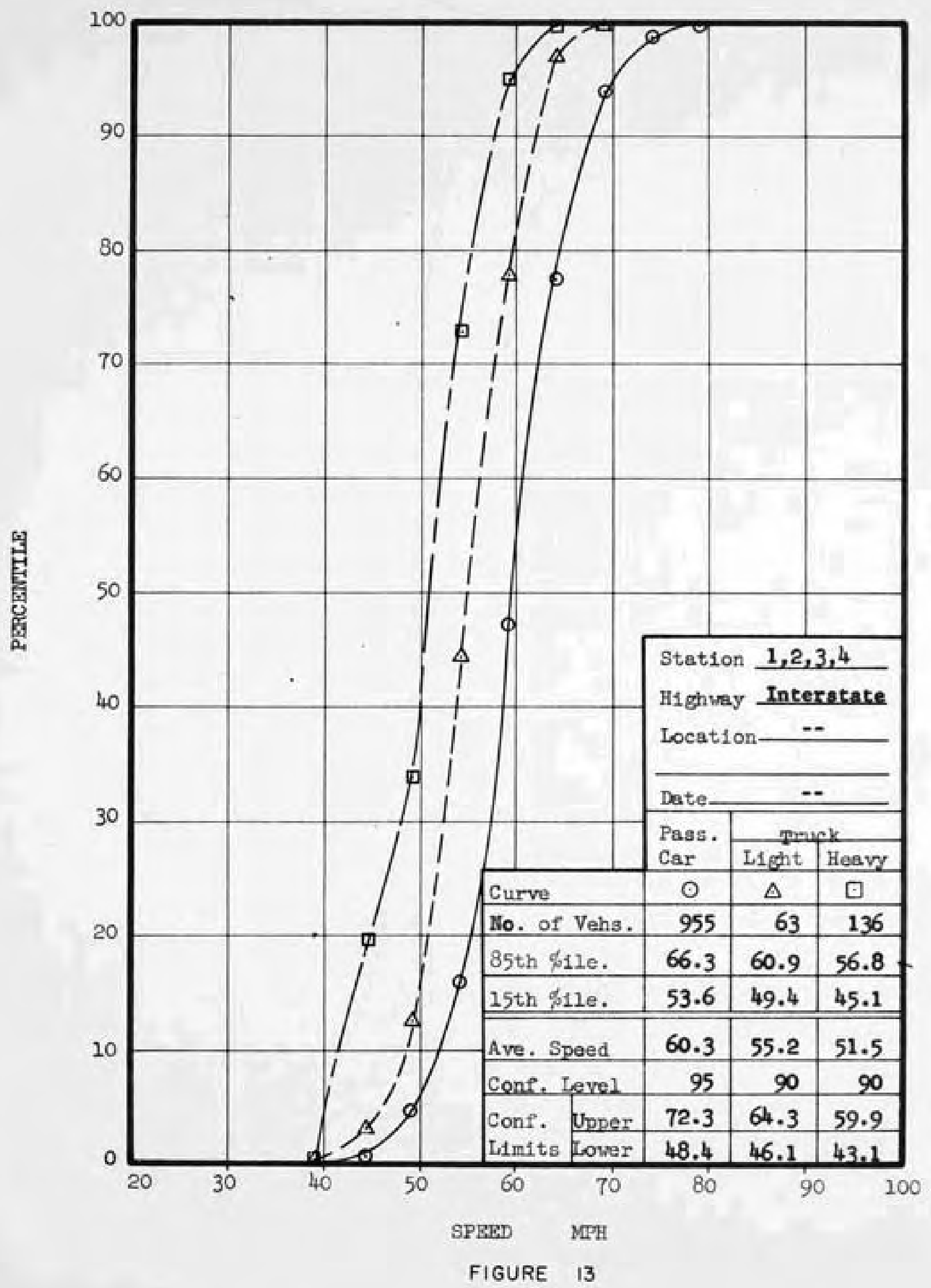




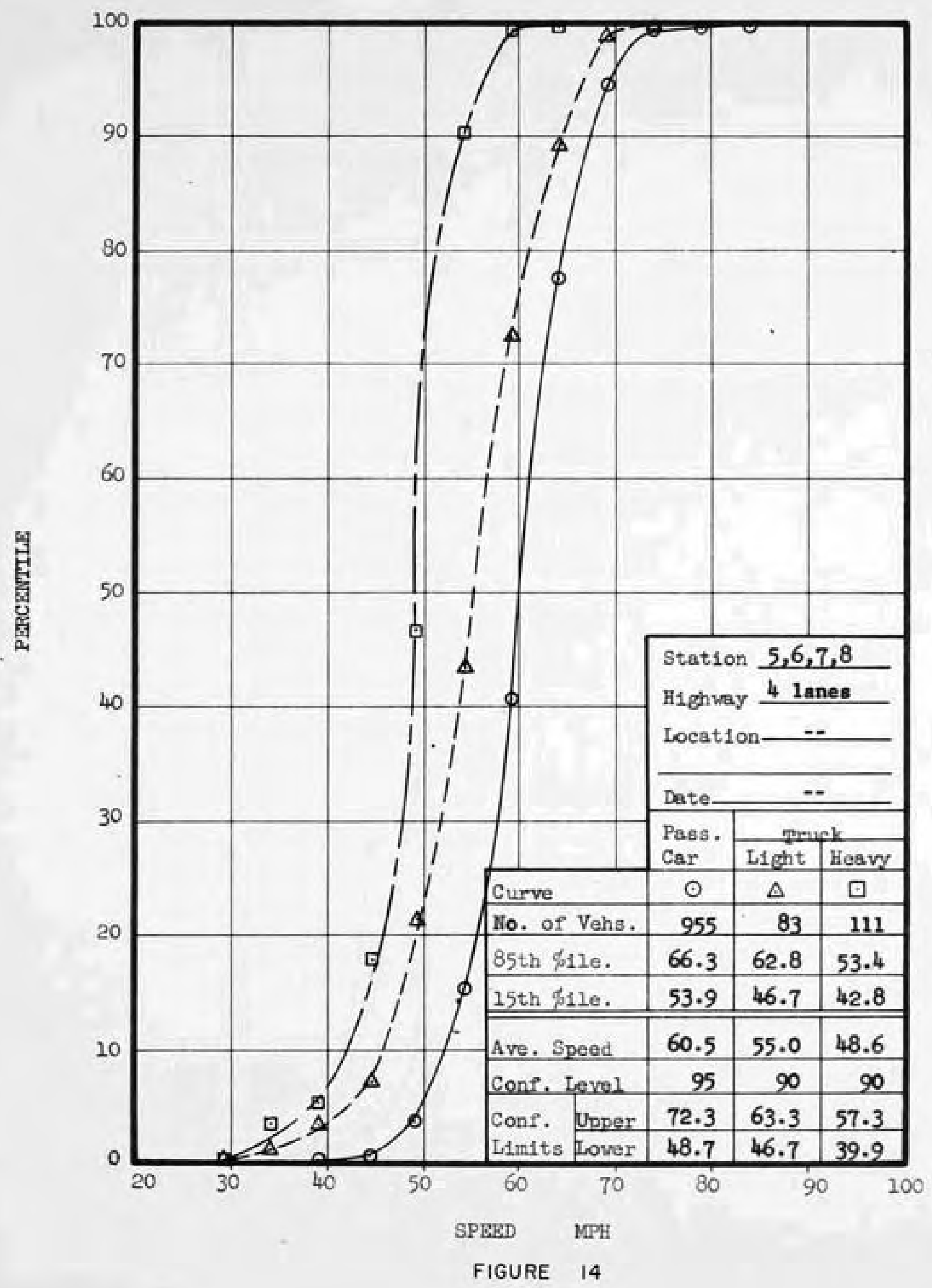




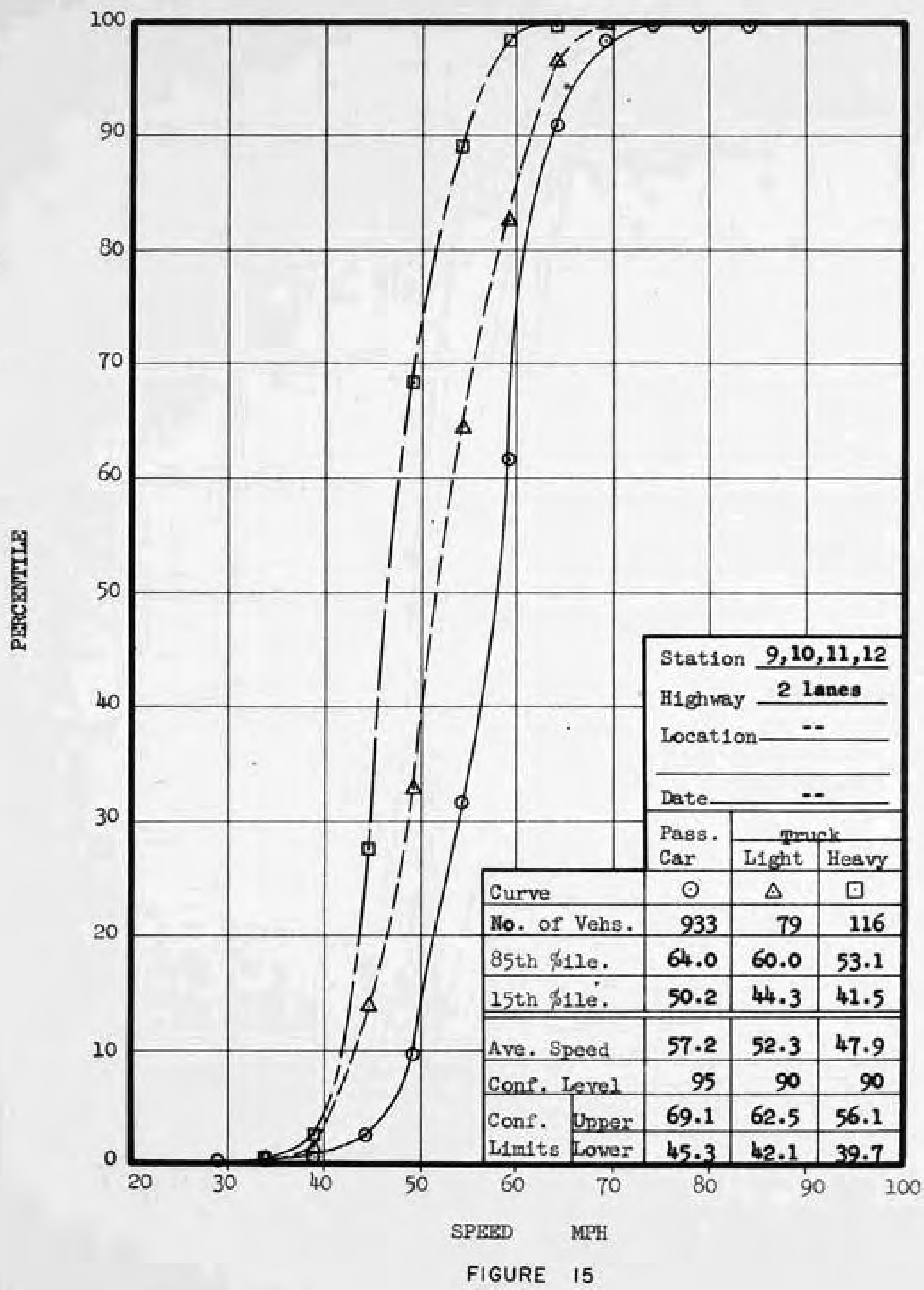




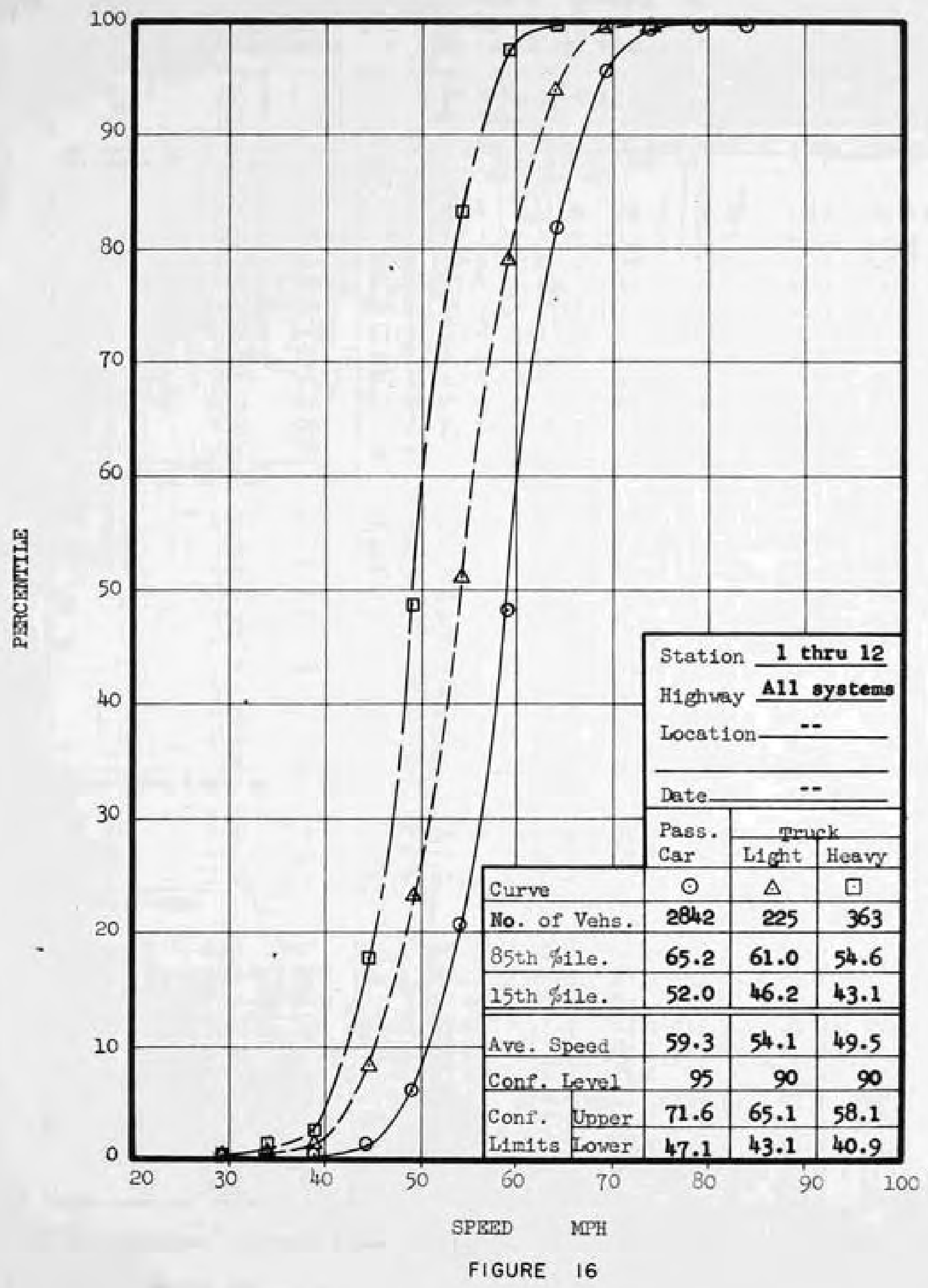


TABLE 17

SURAARY OF SPOT SPEED OBSERVATION

ON INDLANA HIGEMAYS

(Free-Moving Vehicles on Leve1, Tangent Sections)

\begin{tabular}{|c|c|c|c|c|c|c|c|c|c|}
\hline & & & \multicolumn{4}{|c|}{ Passenger Cars } & \multicolumn{3}{|c|}{ Trucks } \\
\hline & & & \begin{tabular}{|l|} 
Ind. \\
Mean \\
\end{tabular} & $\begin{array}{l}\text { Non-Ind. } \\
\text { Mean }\end{array}$ & $\begin{array}{l}\text { A11 } \\
\text { Mean }\end{array}$ & $\begin{array}{c}411 \\
85 \text { per }\end{array}$ & \begin{tabular}{|l|} 
Light \\
Mean
\end{tabular} & $\begin{array}{l}\text { Heavy } \\
\text { Mean }\end{array}$ & $\begin{array}{r}\text { A11 } \\
\text { Mean }\end{array}$ \\
\hline \multicolumn{10}{|c|}{ Two-Lane H1ghways } \\
\hline & $\begin{array}{l}\text { May } \\
\text { Aug. } \\
\text { Aug. } \\
\text { Mar. } \\
\text { Aug. } \\
\text { Mar. } \\
\text { Sept. } \\
\text { Mar. } \\
\text { Aug. } \\
\text { Aug. } \\
\text { Jun. }\end{array}$ & $\begin{array}{l}157 \\
157 \\
158 \\
159 \\
159 \\
160 \\
160 \\
161 \\
161 \\
162 \\
63 \\
\end{array}$ & $\begin{array}{l}55.6 \\
55.5 \\
54.3 \\
55.5 \\
55.6 \\
53.3 \\
55.7 \\
56.7 \\
56.2 \\
56.7 \\
56.9 \\
\end{array}$ & $\begin{array}{l}59.1 \\
56.7 \\
56.3 \\
57.7 \\
55.3 \\
54.8 \\
55.6 \\
56.4 \\
55.7 \\
57.5 \\
57.7\end{array}$ & $\begin{array}{l}56.9 \\
55.9 \\
55.0 \\
56.1 \\
55.9 \\
53.7 \\
55.6 \\
56.6 \\
55.9 \\
57.0 \\
57.2 \\
\end{array}$ & $\begin{array}{l}64.0 \\
62.1 \\
61.7 \\
61.9 \\
63.2 \\
61.2 \\
62.0 \\
63.9 \\
62.2 \\
63.7 \\
64.0 \\
\end{array}$ & $\begin{array}{l}50.2 \\
51.7 \\
53.0 \\
50.4 \\
49.7 \\
48.5 \\
53.0 \\
53.7 \\
50.4 \\
53.1 \\
52.3\end{array}$ & $\begin{array}{l}44.8 \\
45.8 \\
46.3 \\
45.4 \\
46.7 \\
45.9 \\
48.1 \\
47.5 \\
48.9 \\
49.3 \\
47.9\end{array}$ & $\begin{array}{l}46.1 \\
47.3 \\
47.8 \\
46.3 \\
48.0 \\
46.6 \\
49.1 \\
49.3 \\
49.3 \\
50.1 \\
49.7\end{array}$ \\
\hline \multicolumn{10}{|c|}{ Pour-Lane Highways } \\
\hline & $\begin{array}{l}\text { May } \\
\text { Aug. } \\
\text { Aug. } \\
\text { Mar. } \\
\text { Aug. } \\
\text { Mar. } \\
\text { Sept. } \\
\text { Mar. } \\
\text { Aug. } \\
\text { Aug. } \\
\text { Jun. }\end{array}$ & $\begin{array}{l}157 \\
157 \\
158 \\
159 \\
159 \\
160 \\
160 \\
161 \\
161 \\
162 \\
163 \\
\end{array}$ & $\begin{array}{l}59.9 \\
57.5 \\
58.0 \\
58.2 \\
58.4 \\
58.1 \\
59.5 \\
58.9 \\
57.6 \\
59.2 \\
60.4 \\
\end{array}$ & $\begin{array}{l}63.6 \\
59.9 \\
59.6 \\
61.7 \\
60.1 \\
59.2 \\
60.2 \\
61.0 \\
57.6 \\
59.3 \\
60.6 \\
\end{array}$ & $\begin{array}{l}61.0 \\
58.5 \\
58.7 \\
59.0 \\
59.1 \\
58.4 \\
59.7 \\
59.6 \\
57.6 \\
59.2 \\
60.5\end{array}$ & $\begin{array}{l}69.0 \\
64.8 \\
65.0 \\
64.9 \\
64.5 \\
65.0 \\
65.8 \\
66.7 \\
63.5 \\
65.8 \\
66.3\end{array}$ & $\begin{array}{l}52.2 \\
52.0 \\
54.3 \\
53.6 \\
50.0 \\
52.4 \\
54.8 \\
54.0 \\
53.6 \\
54.7 \\
55.0\end{array}$ & $\begin{array}{l}46.0 \\
46.6 \\
49.0 \\
47.0 \\
53.1 \\
47.3 \\
51.3 \\
47.3 \\
50.3 \\
51.3 \\
48.6\end{array}$ & $\begin{array}{l}47.9 \\
47.6 \\
50.0 \\
48.4 \\
49.5 \\
48.4 \\
52.0 \\
48.9 \\
51.0 \\
51.9 \\
51.3\end{array}$ \\
\hline \multicolumn{10}{|c|}{ Interstate Highways } \\
\hline & $\begin{array}{l}\text { Aug. } \\
\text { Aug. } \\
\text { Jun. }\end{array}$ & $\begin{array}{l}161 \\
162 \\
163 \\
\end{array}$ & $\begin{array}{l}56.7 * \\
58.7 \\
59.7\end{array}$ & $\begin{array}{l}56.9 * \\
59.1 \\
61.2 \\
\end{array}$ & $\begin{array}{l}58.2 \\
58.8 \\
60.3\end{array}$ & $\begin{array}{l}64.0 \\
65.6 \\
66.3\end{array}$ & $\begin{array}{l}55.9 \\
55.8 \\
55.2 \\
\end{array}$ & $\begin{array}{l}51.5 \\
52.7 \\
51.5\end{array}$ & $\begin{array}{l}52.4 \\
53.2 \\
52.7\end{array}$ \\
\hline \multicolumn{10}{|c|}{ A11 Highways } \\
\hline & $\begin{array}{l}\text { May } \\
\text { Aug. } \\
\text { Aug. } \\
\text { Mar. } \\
\text { Aug. } \\
\text { Mar. } \\
\text { Sept. } \\
\text { Mar. } \\
\text { Aug. } \\
\text { Aug. } \\
\text { Jun. }\end{array}$ & $\begin{array}{l}157 \\
157 \\
158 \\
159 \\
159 \\
160 \\
160 \\
161 \\
161 \\
162 \\
163 \\
\end{array}$ & $\begin{array}{l}57.2 \\
56.2 \\
55.7 \\
56.6 \\
56.5 \\
55.6 \\
57.3 \\
57.7 \\
56.9 \\
58.2 \\
59.0 \\
\end{array}$ & $\begin{array}{l}60.3 \\
58.3 \\
57.9 \\
59.0 \\
58.4 \\
57.1 \\
57.6 \\
58.3 \\
56.7 \\
58.7 \\
59.9 \\
\end{array}$ & $\begin{array}{l}58.3 \\
56.9 \\
56.5 \\
57.2 \\
57.4 \\
56.0 \\
57.4 \\
57.9 \\
57.3 \\
58.4 \\
59.3\end{array}$ & $\begin{array}{l}66.0 \\
63.2 \\
63.1 \\
63.1 \\
63.5 \\
63.0 \\
63.7 \\
65.1 \\
63.4 \\
65.1 \\
65.2 \\
\end{array}$ & $\begin{array}{l}50.9 \\
51.8 \\
53.4 \\
51.5 \\
50.6 \\
50.2 \\
53.7 \\
53.8 \\
53.1 \\
54.5 \\
54.1 \\
\end{array}$ & $\begin{array}{l}45.2 \\
46.1 \\
47.5 \\
45.9 \\
47.8 \\
46.6 \\
49.4 \\
47.4 \\
50.3 \\
51.2 \\
49.5\end{array}$ & $\begin{array}{l}46.6 \\
47.4 \\
48.7 \\
47.0 \\
48.6 \\
47.5 \\
50.2 \\
49.1 \\
51.0 \\
51.8 \\
51.2\end{array}$ \\
\hline
\end{tabular}

*Includes data for only three of the four stations on Interstate Bighways 


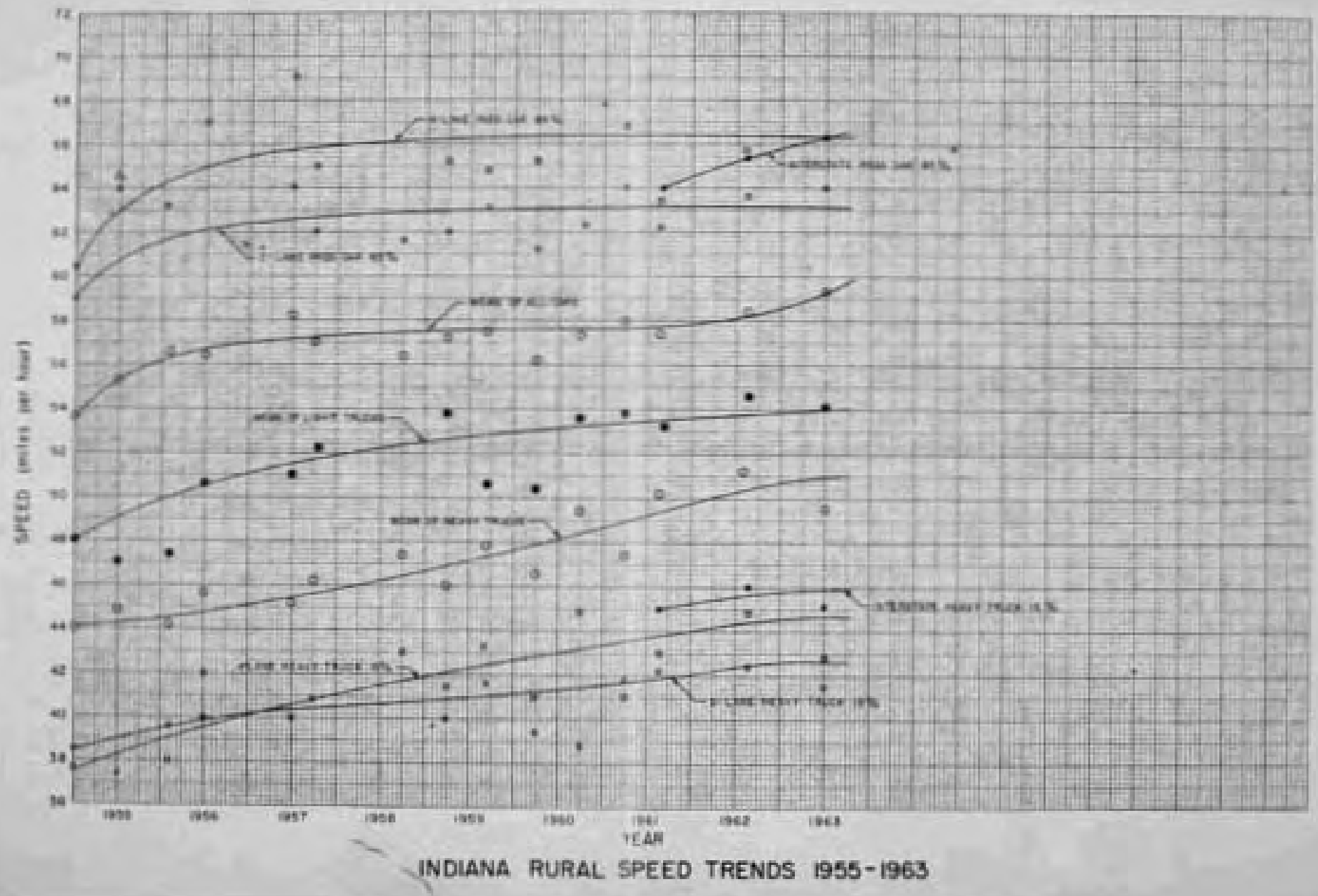

